\title{
CRUSTACEAN VITELLOGENIN: A SYSTEMATIC AND EXPERIMENTAL ANALYSIS OF THEIR GENES, GENOMES, MRNAS AND PROTEINS; AND PERSPECTIVE TO NEXT GENERATION SEQUENCING
}

\author{
BY
}

STEPHANIE JIMENEZ-GUTIERREZ ${ }^{1}$ ), CRISTIAN E. CADENA-CABALLERO²), CARLOS BARRIOS-HERNANDEZ ${ }^{3}$ ), RAUL PEREZ-GONZALEZ ${ }^{1}$ ), FRANCISCO MARTINEZ-PEREZ ${ }^{2,3}$ ) and LAURA R. JIMENEZ-GUTIERREZ ${ }^{1,5}$ )

1) Sea Science Faculty, Sinaloa Autonomous University, Mazatlan, Sinaloa, 82000, Mexico

2 ) Coelomate Genomic Laboratory, Microbiology and Genetics Group, Industrial University of

Santander, Bucaramanga, 680007, Colombia

3 ) Advanced Computing and a Large Scale Group, Industrial University of Santander, Bucaramanga, 680007, Colombia

${ }^{4}$ ) Catedra-CONACYT, National Council for Science and Technology, CDMX, 03940, Mexico

\begin{abstract}
Crustacean vitellogenesis is a process that involves Vitellin, produced via endoproteolysis of its precursor, which is designated as Vitellogenin (Vtg). The Vtg gene, mRNA and protein regulation involve several environmental factors and physiological processes, including gonadal maturation and moult stages, among others. Once the Vtg gene, mRNAs and protein are obtained, it is possible to establish the relationship between the elements that participate in their regulation, which could either be species-specific, or tissue-specific. This work is a systematic analysis that compares the similarities and differences of Vtg genes, mRNA and Vtg between the crustacean species reported in databases with respect to that obtained from the transcriptome of Callinectes arcuatus, C. toxotes, Penaeus stylirostris and $P$. vannamei obtained with MiSeq sequencing technology from Illumina. Those analyses confirm that the Vtg obtained from selected species will serve to understand the process of vitellogenesis in crustaceans that is important for fisheries and aquaculture.
\end{abstract}

\section{RESUMEN}

La vitelogénesis de los crustáceos es un proceso que involucra la vitelina, producida a través de la endoproteólisis de su precursor llamado Vitelogenina (Vtg). La regulación del gen Vtg, los ARNm y la Vtg involucra factores ambientales y procesos fisiológicos, incluyendo: maduración gonadal, etapas de muda, entre otros. Con el gen $V t g$, los ARNm y la proteína obtenidos, es posible correlacionar los elementos que participan en su regulación, pudiendo ser especie-específicos o tejido-específicos. Este trabajo es un análisis sistemático que compara las similitudes y diferencias

${ }^{5}$ ) Corresponding author; e-mail: ljimenez@uas.edu.mx

(C) The authors, 2019

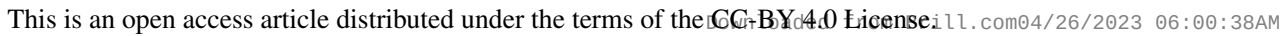


en los genes Vtg, mRNA y Vtg entre especies de crustáceos reportadas en bases de datos contra las obtenidas a partir del transcriptoma de Callinectes arcuatus, $C$. toxotes, Penaeus stylirostris y $P$. vannamei mediante la tecnología de secuenciación MiSeq de Illumina. Éstos análisis confirman la importancia de los estudios de la vitelogénesis en especies de crustáceos de importancia pesquera y acuícola.

\section{INTRODUCTION}

Crustacea have different sexual systems, each aimed at achieving maximum reproduction efficiency in their specific situation. In oviparous species, ovary maturation comprises the synthesis of yolk protein denoted as Vitellin (Vn), which is the most important source of energy and nutrients for embryo development (Boulangé-Lecomte et al., 2017). Vn is produced through the endoproteolysis of its precursor Vitellogenin (Vtg), and both proteins are immunologically similar (Avarre et al., 2003; Zmora et al., 2007; Xie et al., 2009). The process of Vtg biosynthesis and its accumulation in the ovary is named "vitellogenesis", and it is essential for ovarian maturation (Thongda et al., 2015). According to species, Vtg biosynthesis occurs in the ovary and/or hepatopancreas (Shen et al., 2014).

Before the 1990s, most studies focused on ovarian Vtg synthesis; thereafter, crustacean extra-ovarian Vtg synthesis has been well analysed (Jayasankar et al., 2002; Bae et al., 2017). Among species, there are differences between ovarian and extra-ovarian Vtg synthesis (Phiriyangkul et al., 2007). Some proposals to explain this pattern have been established, including applied methodologies, molecular concentration, source of the organisms, among others. The procedures to establish Vtg mRNA concentration in any physiological condition request a correct hybridization between mRNA and the antisense molecule, such as oligonucleotides, complementary DNA (cDNA), or an adequate primer to DNA polymerization. Therefore, the Vtg gen, cDNA and protein sequence are fundamental for a molecular probe design to quantify the mRNA from the genes' expression that participate in crustacean vitellogenesis.

Nowadays, to obtain DNA or RNA sequences quickly in a specific physiological condition, Next Generation Sequencing (NGS) technologies are the better option. They often produce in the order of thousands or hundreds of thousands of sequences, in shorter times and at significantly lower costs (Jimenez-Gutierrez et al., 2016). NGS has been performed in several species of crustaceans; some works have focused on reproduction-involved tissues (He et al., 2012; Gao et al., 2014; Shen et al., 2014), and few of them have yielded physiological implications (Tarrant et al., 2014; Peng et al., 2015; Lee et al., 2017; Das et al., 2018; Uengwetwanit et al., 2018; Wang et al., 2019). In this way, since NGS technologies give new options to identify genes and mRNAs, among which the various Vtg 
transcripts (Shen et al., 2014; Tarrant et al., 2014), NGS is another option to establish the Vtg mRNA expression between maturity stages and sexes (Liu et al., 2015), whose sequences are published in public data bases such as GenBank.

From the available information, most of the Vtg mRNA characterizations from ovary or hepatopancreas were carried out under laboratory conditions. Even though cultured species do not face dramatic climatic changes, many metabolic pathways are circadian-rhythm dependent. In both wild and cultured organisms, many clock genes are strongly related with ovarian development (Tarrant et al., 2014; Chen et al., 2017). Therefore, there currently exists a lack of integration of Vtg mRNAs from crustacean species from fishery, as well as information integration among the different species of crustaceans.

In this work, Vtg mRNAs from the most important crustacean species for the Eastern Pacific fishery (i.e., Callinectes arcuatus Ordway, 1863, C. toxotes Ordway, 1863 and Penaeus stylirostris Stimpson, 1871, and cultured Penaeus vannamei Boone, 1931), were determined with MiSeq Illumina Sequencing Technology. This work sought to deepen the understanding of the different molecules involved in crustacean vitellogenesis, for their use in the evaluation of reproductive periods, and their regulation in different crustacean species of commercial importance.

\section{MATERIAL AND METHODS}

Crustacean genomes, Vtg genes mRNA and Vtg identification in the National Center for Biotechnology Information (NCBI)

To identify the crustacean genomes in the Genome Database from NCBI, the keyword "crustacean" was used. Then, the Vtg gene sequences were identified using the keyword "Vitellogenin" in Genomedata Base whereas the mRNAs were determined from the "GenBank Database" using the same keywords (Benson et al., 2005). To construct the Vtg and Vtg crustacean database, the complete open reading frame (ORF) sequences were used, and partial sequences were discarded.

To corroborate the complete $V t g$ genes mRNAs and protein sequences reported in the respective databases, a Basic Local Alignment Search Tool (BLAST; Altschul et al., 1990) in the NCBI database was made with an Expected Threshold of 100, a Match/Mismatch of 1-2 and 20000 Max Target Sequences. Furthermore, a multiple alignment among Vtg Selected was performed with software Kalign 2.0 (Lopez, 2008; Lassmann et al., 2009; Chojnacki et al., 2017). The alignment parameters were similar to those proposed by the lost DNA model (Martínez-Pérez et al., 2005): output format Clustal W, gap open penalty of 9.0, gap extension penalty 0.2 , terminal gap penalties 0.45 , and bonus score 0.0 . 
The identification of the introns and exons of the reported $V t g$ genes was done according to the reported GenBank sequence and from the respective paper. Furthermore, data from mRNA and ORF of each $V t g$ sequence were corroborated with the alignment among the genomic sequence with the aforementioned parameters. The codons of each exon were established with corresponding amino acids obtained from the ORF translation with the software EXPASY Translate tool (SIB, 2016).

Vitellogenin mRNA phylogenetic tree, and Vtg domains

Determination of the phylogenetic relationships among the sequences of the $V t g$ mRNA was made by Bayesian inference with Mr Bayes software (Ronquist et al., 2012), in 2 runs with 4 Markov-Monte Carlo chains and with a maximum of 30 million generations and sampling every 3000 generations. The Vtg domain identification from each species was done following the protein report from GenBank.

\section{Animal collection}

Wild animals including Callinectes arcuatus, $C$. toxotes and Penaeus stylirostris were obtained from a fishing boat in the East Pacific $\left(23^{\circ} 20^{\prime} \mathrm{N} 106^{\circ} 30^{\prime} \mathrm{W}\right)$, while cultured $P$. vanname $i$ were obtained from an aquaculture farm in Mazatlán, Sinaloa, Mexico $\left(23^{\circ} 1^{\prime} \mathrm{N} 106^{\circ} 12^{\prime} \mathrm{W}\right)$. From the wild animals, a stock from both Vtg synthesis tissues (ovary and hepatopancreas) was used to obtain the transcriptome that represents all maturity stages, the capture season and the circadian rhythm for each species. For the cultured organisms, a stock from each Vtg synthesis tissue (ovary and hepatopancreas), was used to obtain the transcriptome that represents all maturity stages and the circadian rhythm. The details are indicated in table I.

\section{RNA isolation and illumina sequencing}

Total RNA from each tissue stock was obtained with the following protocol: Total RNA was isolated from 100-150 mg of the tissue stock with the Pure Link RNA Mini Kit (Invitrogen / Thermo Fisher Scientific, Waltham, MA) following the manufacturer's instructions and resuspended in $90 \mu \mathrm{l}$ free RNase water. A second round of purification was conducted as follows: a volume of Trizol reagent and $40 \mu \mathrm{l}$ of chloroform were added, then the mixture was vortexed for $10 \mathrm{~s}$ and incubated for $10 \mathrm{~min}$. at $4^{\circ} \mathrm{C}$. The phases were obtained by centrifugation at $13000 \mathrm{~g}$ for $45 \mathrm{~min}$. at $4^{\circ} \mathrm{C}$ to obtain the supernatant. The RNA was precipitated with $90 \mu \mathrm{l}$ of isopropyl alcohol and $10 \mu \mathrm{l}$ of high salt buffer $(0.8 \mathrm{M}$ sodium citrate and $1.2 \mathrm{M} \mathrm{NaCl}$ ) and then incubated over night at $-20^{\circ} \mathrm{C}$. The RNA was 
TABLE I

Sources of collection of the species of Crustacea studied herein

\begin{tabular}{|c|c|c|c|c|c|}
\hline Species & Tissue & $\begin{array}{l}\text { Maturity } \\
\text { stages }\end{array}$ & Collection_date & Day/night & Source \\
\hline $\begin{array}{l}\text { Penaeus vannamei } \\
\text { Boone, } 1931\end{array}$ & $\mathrm{Ov}$ & I to $\mathrm{V}$ & Nov 2018 & $\begin{array}{l}\text { Circadian } \\
\text { rhythm }\end{array}$ & Aquaculture \\
\hline Penaeus vannamei & Hp & I to $\mathrm{V}$ & Nov 2018 & $\begin{array}{l}\text { Circadian } \\
\text { rhythm }\end{array}$ & Aquaculture \\
\hline $\begin{array}{c}\text { Penaeus stylirostris } \\
\text { Stimpson, } 1871\end{array}$ & $\mathrm{Ov} / \mathrm{Hp}$ & $\mathrm{I}$ to $\mathrm{V}$ & Jan 2018-Jan 2019 & Undetermined & Fisheries \\
\hline $\begin{array}{l}\text { Callinectes arcuatus } \\
\text { Ordway, } 1863\end{array}$ & $\mathrm{Ov} / \mathrm{Hp}$ & I to $\mathrm{V}$ & Jan 2018-Jan 2019 & Day & Fisheries \\
\hline $\begin{array}{l}\text { Callinectes toxotes } \\
\text { Ordway, } 1863\end{array}$ & $\mathrm{Ov} / \mathrm{Hp}$ & I to $\mathrm{V}$ & Jan 2018-Jan 2019 & Day & Fisheries \\
\hline
\end{tabular}

Ov, Ovary; Hp, Hepatopancreas.

concentrated by centrifugation at $13000 \mathrm{~g}$ for $55 \mathrm{~min}$. at $4^{\circ} \mathrm{C}$. The pellet was washed two times as follows: $200 \mu \mathrm{l}$ of $70 \%$ ethanol with DEPC water $(0.1 \%$ diethyl pyrocarbonate in Type 1 Water) were used and recovered at the previous speed and temperature centrifugation for $15 \mathrm{~min}$. The RNA was dried off at room temperature and hydrated with $30 \mu \mathrm{l}$ of DEPC water.

Ovarian and hepatopancreas transcriptomic illumina sequencing

All RNA samples were submitted to Genoma Mayor, Universidad Mayor in Chile (Santiago de Chile). The RNA concentration of each sample was determined with QuantiFluor ${ }^{\circledR}$ dsDNA System (Promega, Madison, WI) and the Integrity with Bioanalyzer 2100 RNA 6000 Nano Kit (Agilent Technologies, Santa Clara, CA). The library construction was done using TruSeq Stranded mRNA (Illumina, San Diego, CA). The purity library and size fragments were determined as previously described for total RNA extraction, and the library was sequenced in Illumina MiSeq instrument according to the manufacturer's procedure.

\section{De novo assembly and Vtg analysis}

To obtain each transcriptome, the adapter sequences from each read and lowquality reads were first eliminated with the software Trim-galore, from http://www. bioinformatics.babraham.ac.uk/projects/trim_galore/. The normalization was done with Trinity version 2.6.6 (Haas et al., 2013) with the function: <insilico_read_normalization.pl $>$. The de novo assembled was carried out with the software SPAdes version 3.12.0 at http://cab.spbu.ru/files/release3.12.0/. Finally, to establish the correlation between the sequences assembled and their function, a BLAST alignment 
was done with software Diamond version 0.9.22 versus the "Nucleotide collection" database from NCBI. From these results, the putative Vtg sequences of each species were corroborated with a second BLAST alignment.

\section{RESULTS}

Until November 2018, 27 crustacean genome projects had been reported by the NCBI (see Supplementary Material A-I). From these, six corresponded to the class Branchiopoda, mainly comprising species of the families Triopsidae and Daphniidae. In contrast, the genome of eight of the nine families of the class Hexanauplia had been sequenced. The rest of the genomic projects reported in the NCBI corresponded to species of Malacostraca; however, the majority of these were still under construction.

From the available information, two main Vtg genes had been determined. Both genes, Vtg1 and Vtg2, from Daphnia magna Straus, 1820 have 16 introns and 17 exons, whereas in species of Decapoda, such as Metapenaeus ensis (De Haan, 1844), and Scylla paramamosain Estampador, 1950, the Vtg1 gene has 14 introns and 15 exons, and the Vtg2 gene has fewer than 12 introns and 13 exons (Supplementary Material A-II). The length of the nucleotide sequence of Vtg in the GenBank database ranges from 5000 to $6000 \mathrm{bp}$ in classes such as Branchiopoda and Hexanauplia; meanwhile, in the class Malacostraca, the Vtg sequences range from 7782 to $8518 \mathrm{bp}$. Those genes code for Vtgs varying from 2534 to 2592 amino acids in length (Supplementary Material A-III).

The phylogenetic relationships determined based on nucleotide Vtg sequences of crustacean species showed, that the analysed Decapoda share a common ancestor (fig. 1). There were three main clades: one from the suborder Dendrobranchiata, another for the infraorder Caridea, and the third for the infraorder Brachyura. The evaluated sequences were not separated by tissue of origin, but were catalogued by the species to which they belong. Despite some previously reported transcriptomes that show up to 20 transcripts per species that encode Vtg (Supplementary Material A-IV), in some species, different results with respect to Vtg expression had been reported depending upon the methodology applied (Supplementary Material A-V).

On international databases, the reported Vtg molecular weights range from 200 to $500 \mathrm{kDa}$, according to the species. Vtg from the classes Branchiopoda and Hexanauplia contain less than those from the class Malacostraca. Vtg has conserved regions among the species, especially in their amino terminus, where the Vitellogenin-N domain is located. In this sense, seven domains have been found in species of crustaceans, at least three of which are found in all crustacean species: the domains Vitellogenin-N, Von Willebrand factor type D (VWD), and the 


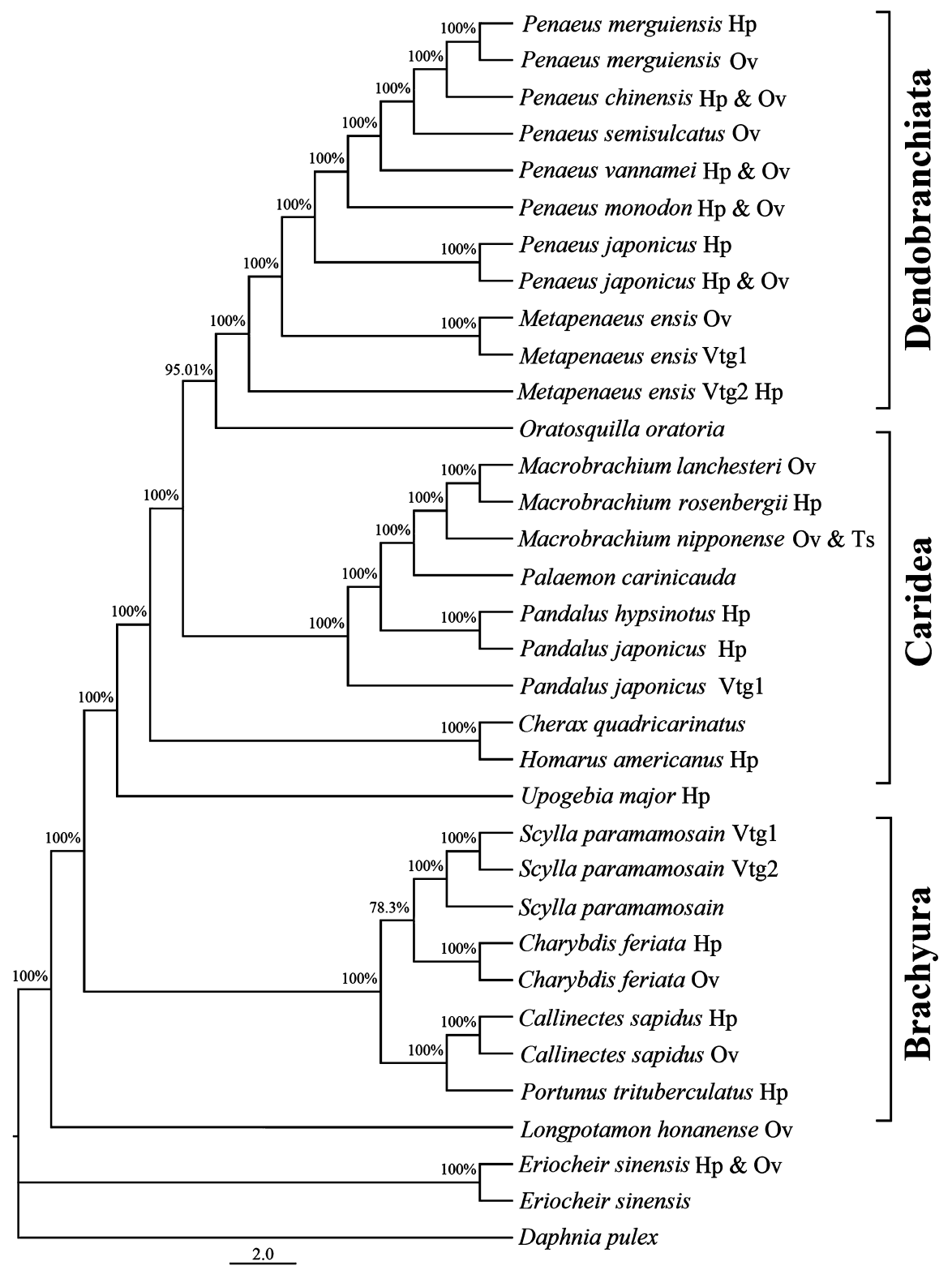

Fig. 1. Phylogenetic tree based on Vtg sequences from species of Crustacea. The nucleotide sequences were aligned with Clustal W software, with the parameters proposed in the DNA loss model (Martinez-Perez, 2005). The phylogeny with Bayesian inference was obtained with MrBayes software with 2 runs, and 4 Markov-Monte Carlo chains, with Daphnia pulex Leydig, 1860, as an outgroup. Numbers above the nodes indicate nonparametric bootstrap values (30 million generations, sampling the chains every 3000 generations). Sequences that specify the tissue of origin are marked with the suffixes Hp, Hepatopancreas; Ov, Ovary; Ts, Testicle. The access numbers are indicated in the table Supplementary Material A-II. 


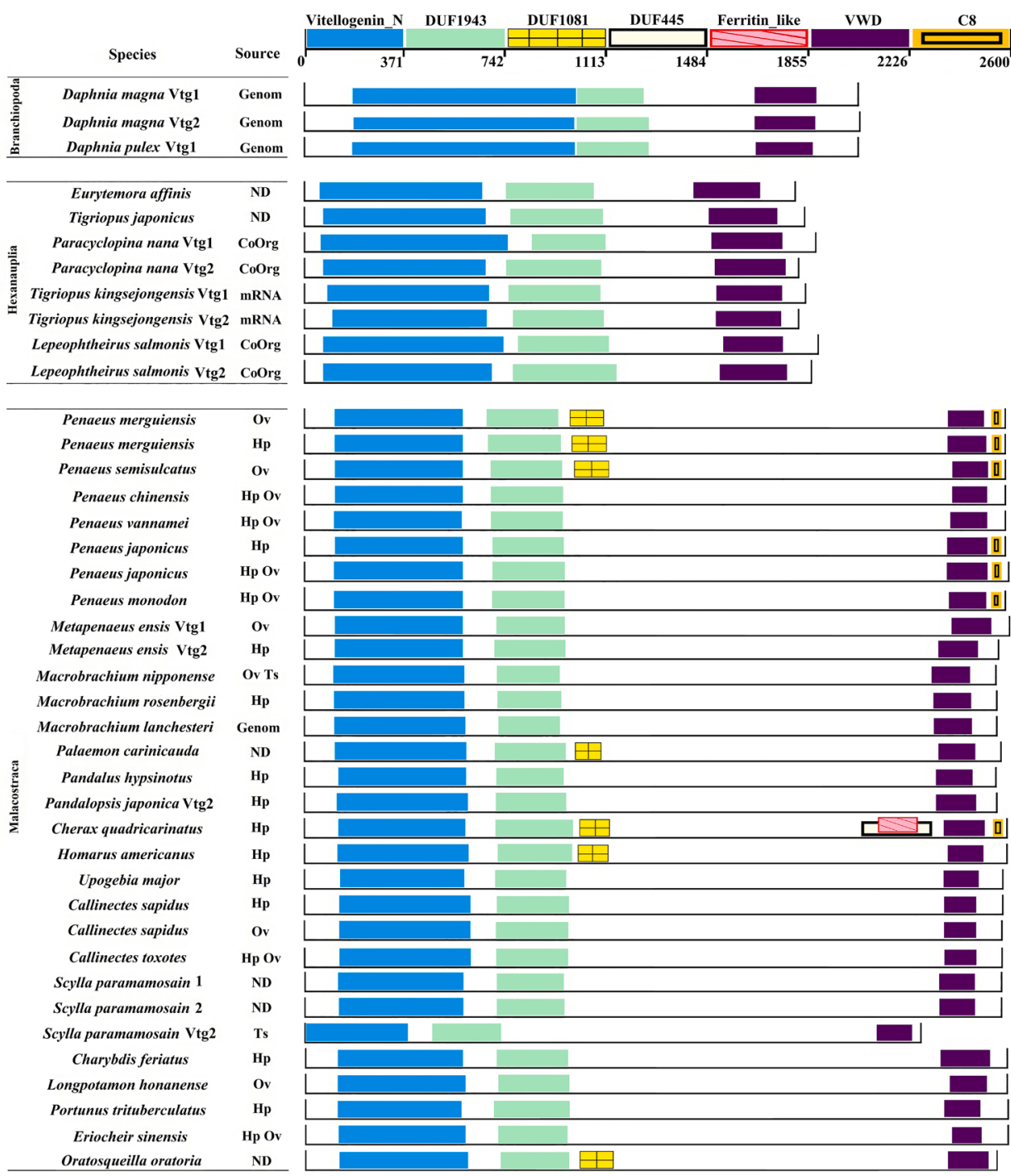

Fig. 2. Domain locations from crustacean Vtg sequences reported in GenBank. Each region is indicated in its respective colour. The positions of each domain are indicated in the table Supplementary Material A-VI. Sources: Genom, Genomic; CoOrg, Complete Organism; Hp, Hepatopancreas; Ov, Ovary; Ts, Testicle; HP OV, Hepatopancreas \& Ovary; Ov Ts, Ovary \& Testicle; ND, Not Determined.

Domain of Unknown Function (DUF) DUF1943 (fig. 2; Supplementary Material A-VI). Other domains that are exclusively present in Malacostraca are the Ferritinlike domain, the $\mathrm{C} 8$ domain, and the VWD domain.

Some publications related to Vtg synthesis show more than one Vtg; however, in the GenBank database one Vtg sequence is exclusively reported for most 
TABLE II

The similarity of Vtg sequences from hepatopancreas and ovary from several species of decapod Crustacea

\begin{tabular}{lllc}
\hline Species & \multicolumn{2}{c}{ Accession numbers } & \multirow{2}{*}{ Similarity (\%) } \\
\cline { 2 - 3 } & Ovary & Hepatopancreas & \\
\hline Penaeus merguiensis (De Man, 1888) & AAR88442.2 & ACV32381.1 & 99 \\
Penaeus vannamei Boone, 1931* & AAP76571.2 & AGX26044.1 & 99 \\
Penaeus vannamei** & MN105877 & MN105878 & 69 \\
Callinectes sapidus Rathbun, 1896 & AEI59132.1 & ABC41925.1 & 98 \\
Cherax quadricarinatus $($ Von Martens, 1868)** & AAS68191.1 & AAG17936.1 & 54 \\
Metapenaeus ensis (De Haan, 1844)* & AAN40700.1 & AAN86120.1 & 42 \\
\hline
\end{tabular}

* Vtg sequence from the hepatopancreas (HP) is incomplete.

** Vtg sequence from the ovary (OV) is incomplete.

crustaceans, with an exception for species such as Penaeus merguiensis (De Man, 1888), P. vannamei, M. ensis, Cherax quadricarinatus (Von Martens, 1868), and Callinectes sapidus Rathbun, 1896, which have Vtg sequences reported from both tissues (hepatopancreas and ovary). Complete Vtg sequences from both tissues are almost identical. However, for some of these sequences, at least one is incomplete. In the specific case of previously reported P. vannamei, the partial Vtg sequence was from the amino-terminal region, which is the most conserved region. In our results, the partial ovary Vtg sequence carboxyl-terminal region has a similarity of $69 \%$ with hepatopancreas Vtg. In contrast, for C. quadricarinatus and $M$. ensis, the partial sequences were from the carboxyl-terminal region, which is why the similarity of the sequences that could be checked drops to $54 \%$ and $42 \%$, respectively (table II).

Transcriptomes from cultured P. vannamei and wild Penaeus stylirostris, Callinectes arcuatus and $C$. toxotes allow to identify the Vtg sequences and their deduced proteins (table III). The P. vannamei complete Vtg from hepatopancreas shares $69 \%$ similarity with partial carboxyl-terminal ovary Vtg. In general, all Vtg sequences presented identities greater than $90 \%$ with those from previously reported species, including other species of the same genus. The effect of neuropeptides and physiological conditions on Vtg expression and synthesis in crustaceans is illustrated in Supplementary Material A-VII.

\section{DISCUSSION}

Traditional and NGS technologies can help to establish genomes and transcriptomes. From the available genomes, the number and arrangement of the introns/exons are species-specific (Martínez-Pérez et al., 2009). The numbers of Vtg introns 


\section{TABLE III}

Vtg mRNA from Penaeus vannamei Boone, 1931, P. stylirostris Stimpson, 1871, Callinectes arcuatus Ordway, 1863, and C. toxotes Ordway, 1863, and their similarities with previously reported crustaceans, among which Callinectes sapidus Rathbun, 1896

\begin{tabular}{llccl}
\hline Species & Tissue & $\begin{array}{c}\text { Vtg accession } \\
\text { number }\end{array}$ & $\begin{array}{c}\text { Deduced protein } \\
\text { similarity (\%) }\end{array}$ & GenBank species \\
\hline Penaeus vannamei & $\mathrm{Ov}$ & MN105877.1 & 99.4 & P. vannamei ROT61469.1 \\
Penaeus vannamei & $\mathrm{Hp}$ & $\mathrm{MN} 105878.1$ & 94 & P. vannamei AAP76571.2 \\
Penaeus stylirostris & $\mathrm{Ov} / \mathrm{Hp}$ & $\mathrm{MN} 105879.1$ & 99 & P. vannamei ROT61470.1 \\
Callinectes arcuatus & $\mathrm{Ov} / \mathrm{Hp}$ & $\mathrm{MN} 105880.1$ & 93.1 & C. sapidus AEI59132.1 \\
Callinectes toxotes & $\mathrm{Ov} / \mathrm{Hp}$ & $\mathrm{MN} 105881.1$ & 91.7 & C. sapidus AEI59132.1 \\
\hline
\end{tabular}

Ov, ovary; Hp, hepatopancreas.

and exons from crustacean species are like those from other invertebrate and vertebrate species, suggesting a common ancestor (Kung et al., 2004). Nevertheless, the higher number of introns of Branchiopoda with respect to Malacostraca is directly related to their lower number of base pairs on Vtg sequences and to the higher specialization of Vtg of Malacostraca species.

Despite the presence of at least two Vtg sequences reported for several species, in the phylogenetic tree, the sequences are not separated according to the tissue of origin but according to species. This suggests a possible alternative splicing and punctual mutations within each species (Tarrant et al., 2014; Liu et al., 2015). Some authors have suggested a divergent evolutionary process (Tarrant et al., 2014; Liu et al., 2015).

The Vtg transcript of vertebrates is encoded by a multigene family (Tarrant et al., 2014). But in the invertebrates, only for Procambarus clarkii (Girard, 1852), 29 transcripts were reported that encode Vtg (Shen et al., 2014). Our results from each tissue, which agree with previous reports, suggest possible alternative mRNA splicing events (Mak et al., 2005) or an early gene duplication event, followed by rapid sequence divergence (Phiriyangkul et al., 2007), which represent phenomena that are not limited to the infraorder group and neither by their geographical distribution.

Most works have focused on differential tissue expression of Vtg in female crustaceans. For example, in the shrimp Metapenaeus ensis, Vtgl is expressed in ovary and hepatopancreas, whereas $V t g 2$ is expressed exclusively in the hepatopancreas (Wong et al., 2008). However, a main point of discussion is which organ is the major site of synthesis. A major Vtg expression in the hepatopancreas has been reported for some crustacean species, such as the shrimps Penaeus japonicus Spence Bate, 1888 (cf. Okumura, 2007), P. merguiensis (cf. Phiriyangkul et al., 2007), $P$. vannamei (cf. Raviv et al., 2006) and M. ensis (cf. Tsang et al., 2003; Tiu et al., 2006a), the freshwater crayfish Procambarus clarkii, and the blue swimming crab 
Callinectes sapidus (cf. Shen et al., 2014; Thongda et al., 2015). Nonetheless, the results depend upon the methodologies applied.

With genome databases, Vtg genes, mRNA and Vtg proteins, in this work, the $V t g$ is confirmed in ovary/hepatopancreas transcriptomes from the wild-caught crustaceans $C$. arcuatus, $C$. toxotes and $P$. stylirostris in addition to the ovary and hepatopancreas transcriptomes from cultured $P$. vannamei. Even so, there are some previously published transcriptomes from $P$. vannamei with Illumina MiSeq technology, most of which do not have a reproductive focus (Zhang et al., 2016; Fan et al., 2019), and some of them are focused on eyestalk tissue (Wang et al., 2019) and changes in hepatopancreas after eyestalk ablation (Lee et al., 2017). Next to Vtg, some other mRNAs have been implicated in reproduction control, such as the Vtg receptor (VtgR; Shen et al., 2014), the GonadotropinReleasing Hormone (GnRH) signalling pathway (among them: GnRH receptor and epidermal growth factor receptor), Torso-like, and Vigillin, among others (Tarrant et al., 2014; Uengwetwanit et al., 2018).

Preliminary transcriptomic results from P. vannamei, P. stylirostris, C. arcuatus and C. toxotes help to find some reproduction-related genes such as $V t g R$, vitelline membrane outer protein, vitellogenin carboxipeptidase, ecdysone receptor $(E c R)$, ecdysteroid-regulated protein, ecdysone-induced protein, progesteronelike protein, progesterone-induced-blocking factor, progesterone receptor, crustacean female sex hormone ovarian isoform, lutropin-choriogonadotropic hormone receptor, ovarian peritrophin, ovary development related protein, ovigeroushair stripping substance, ovoinhibidor, ovarian killer protein, ecdysteroid receptor, ecdysteroid-regulated protein, ecdysone-induced protein, voltage-dependent calcium channel, FEM-1, and insulin growth factor, among others.

Most of these could serve as molecular markers of maturity stages, as well as to study the interactions in the induction and repression of reproduction. However, further studies are necessary to understand the role of each one on the reproduction of crustaceans.

Despite the substantial amount of information generated from NGS, there remains a large number of unknown genes and functions, because organisms have phenotypic plasticity, i.e., the ability to express different phenotypes from the same genotype due to changes in environmental conditions (An et al., 2018). Also, the complete genome of most crustaceans is unknown, and there is a limited number of non-redundant sequences in the international databases for some species.

\section{Vtg synthesis}

Vtg is a member of a family of lipid transfer proteins (Smolenaars et al., 2007). The classes Branchiopoda and Hexanauplia have fewer amino acids as compared 
to the class Malacostraca. The fact that Malacostraca species present more domains implies a higher level of regulation and more possible functions for Vtg. The Vitellogenin- $\mathrm{N}$ domain is the core of the protein, and transfers cholesterol and triglycerides to Vtg (Bai et al., 2015). The Ferritin-like domain stores iron in a biologically available form. The GL/ICG motifs from the C8 and VWD domains are necessary for the oligomerization of the protein (Bai et al., 2015; Wu et al., 2018). In addition to these domains from crustacean Vtg, some motifs, such as R-K.XXR, KLSR, KCYR, and KFSR, are found in mammals, insects, and crustaceans (Xie et al., 2009). These have been proposed as processing motifs for the subtilisin-like protease family (Tseng et al., 2001).

Vtg is composed of two subunits in the early stages of vitellogenesis and of four subunits in the late stages of vitellogenesis, which is congruent with Western blot immunopositive signals concentrated on the lower-molecular-weight fraction of the ovarian polypeptide (Okuno et al., 2002; Zmora et al., 2007). Vtg subunits have been detected by ELISA assays in the ovary, haemolymph, and hepatopancreas; however, in some crustacean species, Vtg was not found in the hepatopancreas, despite the presence of the Vtg transcript (Auttarat et al., 2006). In some species, Vtg levels in the hepatopancreas at any stage are low or undetectable by Western blot (Auttarat et al., 2006; Phiriyangkul et al., 2007).

This suggests that the demand for Vtg from the ovary is greater than the rate of synthesis from the hepatopancreas (Auttarat et al., 2006), whereas in the ovaries the concentrations of Vtg during ovarian maturation are lower than those of Vn (Auttarat et al., 2006; Wong et al., 2008). This is likely because Vtg may be excreted from the hepatopancreas immediately after synthesis and/or due to the great number of proteases already present in this organ (Phiriyangkul \& Utarabhand, 2006; Zmora et al., 2009). In some cases, the presence of small Vtg peptides depends upon the accurate preservation of the sample, because even under a congelation point, RNases and proteases have activity (Auttarat et al., 2006).

\section{Ovary development and maturation}

Regardless of the presence of one or two Vtg transcripts, their expression is strictly related to the oogenic cycle (Raviv et al., 2006), and Vtg levels in the haemolymph are often indicative of ovarian development (Thongda et al., 2015). For most crustacean species, ovarian development is separated into four stages (Nguyen et al., 2018) and external conditions are intimately connected with ovarian maturation, depending mostly on the season of the year, with maximum reproduction peaks in seasons with higher temperatures (Thongda et al., 2015).

Previous reports show a species-specific Vtg expression pattern. For most crustaceans, both Vtg transcription and yolk volume increase in parallel to ovarian 
maturation (Kung et al., 2004). For the shrimps Penaeus merguiensis, $P$. indicus H. Milne Edwards, 1837 and P. vannamei, the Vtg expression levels are higher in the ovary than in the hepatopancreas at all evaluated stages (Phiriyangkul \& Utarabhand, 2006; Raviv et al., 2006), whereas for the shrimp P. japonicus, the expression pattern is the opposite (Tsutsui et al., 2000). The highest Vtg mRNA levels from the ovarian tissue of $P$. merguiensis were observed in the early vitellogenic stage, and these decrease in advanced stages, with an opposite expression pattern in the hepatopancreas (Phiriyangkul et al., 2007). However, in some reports for P. japonicus (cf. Okumura, 2007), and Scylla paramamosain (cf. Jia et al., 2013), a constant increase occurs from the primary vitellogenetic stage to final maturation, with a decrease after oviposition.

In some species of decapods, such as the mud crab $S$. paramamosain (cf. Gong et al., 2015) and the prawn Macrobrachium rosenbergii (De Man, 1879) (cf. Okuno et al., 2002), the ovary is only known as a site for Vtg uptake and accumulation during ovarian development (Gong et al., 2015), synthesizing only small amounts of Vtg (Tiu et al., 2006b). In other species, such as the ridgeback prawn Sicyonia ingentis (Burkenroad, 1938), the shrimp P. japonicus and the swimming crab Callinectes sapidus (cf. Tsukimura, 2001; Okumura, 2007; Thongda et al., 2007; Zmora et al., 2007), Vtg synthesis occurs in both tissues. We have found Vtg transcripts in both tissues from adult females of the Pacific blue swimming crab C. arcuatus and also in the hepatopancreas of subadult females of P. stylirostris (without developed gonads), whereas in subadult females of P. vannamei, Vtg transcripts were absent.

It is important to highlight these physiological differences and the speciesspecific regulation level, because in tropical countries, fishery management is generalized for all members of the same crustacean family (e.g., in the families Peneidae and Portunidae; NOM-039-PESC, 2003; NOM-002-SAG/PESC, 2013), despite differences in the regulation of their reproduction. In this sense, Vtg sequences for species that are not cultured commercially, such as the shrimp $P$. stylirostris and the crabs $C$. arcuatus and $C$. toxotes, among others, are less studied and were absent in the GenBank databases until this work.

All of the abovementioned studies suggest a perfectly coordinated process among the hepatopancreas and ovary, where the genes $V t g, V t g R$ and $E c R$, among others, could be potential markers for evaluating ovarian maturation in each species. However, Vtg expression and Vtg synthesis patterns are not the same for all infraorders from the subphylum Crustacea, not even among members of the same genus. Evaluations must be standardized by each species, and by each habitat, without neglecting the evolutionary history of each gene. An understanding of all of these physiological processes can be used to assay the crustacean reproduction process in both aquaculture and fisheries. 


\section{ACKNOWLEDGEMENTS}

We thank projects CONACYT (National Council for Science and Technology) Basic Science 2015-255664, and the project 5713 from the Vice-Rectory of Investigation of the Industrial University of Santander. We also thank the Advanced Computing and a Large Scale Group of the Industrial University of Santander (SC3-UIS), supported by the Vice-Rector for Investigation and Extension of the Industrial University of Santander, for their support in the nucleotide and protein analyses.

\section{REFERENCES}

Altschul, S. F., W. Gish, W. Miller, E. W. Myers \& D. J. Lipman, 1990. Basic local alignment search tool. J. Mol. Biol., 215: 403-410. DOI:10.1016/S0022-2836(05)80360-2.

An, H., T. Do, G. Jung, M. Z. Karagozlu \& C. B. KiM, 2018. Comparative transcriptome analysis for understanding predator-induced polyphenism in the water flea Daphnia pulex. Int. J. Mol. Sci., 19: 1-13. DOI:10.3390/ijms19072110.

Auttarat, J., P. Phiriyangkul \& P. Utarabhand, 2006. Characterization of vitellin from the ovaries of the banana shrimp Litopenaeus merguiensis. Comp. Biochem. Physiol., (B, Biochem. Mol. Biol.) 143: 27-36. DOI:10.1016/j.cbpb.2005.09.009.

Avarre, J. C., R. Michelis, A. Tietz \& E. Lubzens, 2003. Relationship between vitellogenin and vitellin in a marine shrimp (Penaeus semisulcatus) and molecular characterization of vitellogenin complementary DNAs. Biol. Reprod., 69: 355-364. DOI:10.1095/biolreprod.102. 011627.

BAe, S. H., T. OKutsu, N. Tsutsui, B. J. KAnG, H. Y. Chen \& M. N. Wilder, 2017. Involvement of second messengers in the signaling pathway of vitellogenesis-inhibiting hormone and their effects on vitellogenin mRNA expression in the whiteleg shrimp, Litopenaeus vannamei. Gen. Comp. Endocrinol., 246: 301-308. DOI:10.1016/j.ygcen.2017.01.006.

Bai, H., H. QiaO, F. LI, H. Fu, S. Sun, W. Zhang, S. Jin, Y. Gong, S. Jiang \& Y. XIONG, 2015. Molecular characterization and developmental expression of vitellogenin in the Oriental river prawn Macrobrachium nipponense and the effects of RNA interference and eyestalk ablation on ovarian maturation. Gene, 562: 22-31. DOI:10.1016/j.gene.2014.12.008.

Benson, D. A., I. Karsch-Mizrachi, D. J. Lipman, J. Ostell \& D. L. Wheeler, 2005. GenBank. Nucleic Acids Res., 33: 34-38. DOI:10.1093/nar/gki063.

Boulangé-Lecomte, C., B. Xuereb, G. Trémolet, A. Duflot, N. Giusti, S. Olivier, E. LEGRAND \& J. FORGET-LERAY, 2017. Controversial use of vitellogenin as a biomarker of endocrine disruption in crustaceans: new adverse pieces of evidence in the copepod Eurytemora affinis. Comp. Biochem. Physiol., (C, Toxicol. Pharmacol.) 201: 66-75. DOI:10.1016/j.cbpc. 2017.09.011.

Chen, S., H. Qiao, H. Fu, S. Sun, W. Zhang, S. Jin, Y. Gong, S. Jiang, W. Xiong \& Y. WU, 2017. Molecular cloning, characterization, and temporal expression of the clock genes period and timeless in the Oriental river prawn Macrobrachium nipponense during female reproductive development. Comp. Biochem. Physiol., (A, Mol. Integr. Physiol.) 207: 43-51. DOI:10.1016/j.cbpa.2017.02.011.

Chojnacki, S., A. Cowley, J. Lee, A. Foix \& R. Lopez, 2017. Programmatic access to bioinformatics tools from EMBL-EBI update: 2017. Nucleic Acids Res., 45: 550-553. DOI: 10. 1093/nar/gkx273. 
Das, S., L. VRaspir, W. Zhou, D. S. Durica \& D. L. Mykles, 2018. Transcriptomic analysis of differentially expressed genes in the molting gland (Y-organ) of the blackback land crab, Gecarcinus lateralis, during molt-cycle stage transitions. Comp. Biochem. Physiol., (D, Genomics Proteomics) 28: 37-53. DOI:10.1016/j.cbd.2018.06.001.

FAn, L., Z. WAng, M. Chen, Y. QU, J. Li, A. Zhou, S. XIE, F. Zeng \& J. ZoU, 2019. Microbiota comparison of Pacific white shrimp intestine and sediment at freshwater and marine cultured environment. Sci. Total Environ., 20: 1194-1204. DOI:10.1016/j.scitotenv.2018.12.069.

GAO, J., X. WANG, Z. ZoU, X. JiA, Y. WANG \& Z. ZhAng, 2014. Transcriptome analysis of the differences in gene expression between testis and ovary in green mud crab (Scylla paramamosain). BMC Genomics., 15: 1-15. DOI:10.1186/1471-2164-15-585.

Gong, J., H. Ye, Y. Xie, Y. YAng, H. Huang, S. Li \& C. Zeng, 2015. Ecdysone receptor in the mud crab Scylla paramamosain: a possible role in promoting ovarian development. J. Endocrinol., 224: 273-287. DOI:10.1530/JOE-14-0526.

HaAs, J. B., A. Papanicolaou, M. Yassour, M. Grabherr, P. D. Blood, J. Bowden, M. B. Couger, D. Eccles, B. Li, M. Lieber, M. D. MacManes, M. Ott, J. Orvis, N. Pochet, F. Strozzi, N. Weeks, R. Westerman, T. William, C. N. Dewey, R. Henschel, R. D. LEDUC, N. FRIEDMAN \& A. REgEV, 2013. De novo transcript sequence reconstruction from RNA-seq using the Trinity platform for reference generation and analysis. Nat. Protoc., 8: 1494-1512. DOI:10.1038/nprot.2013.084.

He, L., Q. WANG, X. Jin, Y. WANG, L. Chen, L. LiU \& Y. WANG, 2012. Transcriptome profiling of testis during sexual maturation stages in Eriocheir sinensis using illumina sequencing. PLoS One, 7: 1-9. DOI:10.1371/journal.pone.0033735.

Jayasankar, V., N. Tsutsui, S. Jasmani, H. Saido-Sakanaka, W. J. Yang, A. Okuno, T. T. Thani, H. Hien, K. AidA \& M. N. Wilder, 2002. Dynamics of vitellogenin mRNA expression and changes in hemolymph vitellogenin levels during ovarian maturation in the giant freshwater prawn Macrobrachium rosenbergii. J. Exp. Zool., 293: 675-682. DOI:10.1002/ jez.10167.

JiA, C., C. B. Lietz, H. Ye, L. Hui, Q. YU, S. Yoo \& L. Li, 2013. A multi-scale strategy for discovery of novel endogenous neuropeptides in the crustacean nervous system. J. Proteomics, 91: 1-12. DOI:10.1016/j.jprot.2013.06.021.

Jimenez-Gutierrez, L. R., C. J. Barrios-Hernández, G. R. PedraZA-Ferreira, L. VeraCALA \& F. MARTINEZ-PEREZ, 2016. Importance of databases of nucleic acids for bioinformatics analysis focused to genomics. J. Phys. Conf. Ser., 743: 1-4. DOI:10.1088/1742-6596/ 743/1/012009.

Kung, S. Y., S. M. Chan, J. H. Hui, W. S. Tsang, A. MaK \& J. G. He, 2004. Vitellogenesis in the sand shrimp, Metapenaeus ensis: the contribution from the hepatopancreas-specific vitellogenin gene (MeVg2). Biol. Reprod., 71: 863-870. DOI:10.1095/biolreprod.103.022905.

LASSMAnn, T., O. Frings \& E. L. L. Sonnhammer, 2009. Kalign2: high-performance multiple alignment of protein and nucleotide sequences allowing external features. Nucleic Acids Res., 37: 858-865. DOI:10.1093/nar/gkn1006.

LeE, J. H., I. T. Suryaningtyas, T. Yoon, J. M. Shim, H. PARK \& H. Kim, 2017. Transcriptomic analysis of the hepatopancreas induced by eyestalk ablation in shrimp, Litopenaeus vannamei. Comp. Biochem. Physiol., (D, Genomics Proteomics) 24: 99-110. DOI:10.1016/j.cbd.2017.08. 004.

LiU, Y., M. Hui, Z. Cui, D. LuO, C. Song, Y. Li \& L. LiU, 2015. Comparative transcriptome analysis reveals sex-biased gene expression in juvenile Chinese mitten crab Eriocheir sinensis. PLoS One, 10: 1-21. DOI:10.1371/journal.pone.0133068.

Lopez, R., 2008. Biological data resources at the EMBL-EBI. Rev. Colomb. Biotecnol., 10: 120128. DOI:10.15446/rev.colomb.biote. 
MaK, A. S. C., C. L. Choi, S. H. K. Tiu, J. H. L. Hui, J. G. He, S. S. Tobe \& S. Chan, 2005. Vitellogenesis in the red crab Charybdis feriatus: hepatopancreas-specific expression and farnesoic acid stimulation of vitellogenin gene expression. Mol. Reprod. Dev., 70: 288300. DOI:10.1002/mrd.20213.

Martínez-PÉrez, F., W. G. Bendena, B. S. Chang \& S. S. Tobe, 2009. FGLamide Allatostatin genes in Arthropoda: introns early or late? Peptides, 30: 1241-1248. DOI:10.1016/j.peptides. 2009.04.001.

Martínez-Pérez, F., D. Durán-Gutiérrez, L. Delaye, A. Becerra, G. Aguilar \& S. ZINKER, 2007. Loss of DNA: a plausible molecular level explanation for crustacean neuropeptide gene evolution. Peptides., 28: 76-82. DOI:10.1016/j.peptides.2006.09.021.

Nguyen, T. V., G. E. Rotllant, S. F. Cummins, A. Elizur \& T. Tomer, 2018. Insights into sexual maturation and reproduction in the Norway lobster (Nephrops norvegicus) via in silico prediction and characterization of neuropeptides and $\mathrm{G}$ protein-coupled receptors. Front. Endocrinol., 9: 1-16. DOI:10.3389/fendo.2018.00430.

NOM-002-SAG/PESC, 2013. Para ordenar el aprovechamiento de las especies de camarón en aguas de jurisdicción federal de los Estados Unidos Mexicanos. Diario Oficial de la Federación. Available at: http://www.dof.gob.mx/nota_detalle_popup.php?codigo=5306294.

NOM-039-PESC, 2003. Pesca responsable de jaiba en aguas de jurisdicción federal del litoral del Océano Pacífico. Especificaciones para su aprovechamiento. Diario Oficial de la Federación. Available at: http://dof.gob.mx/nota_detalle.php?codigo=4926205andfecha=26/07/2006.

OKUMURA, T., 2007. Effects of bilateral and unilateral eyestalk ablation on vitellogenin synthesis in immature female kuruma prawns, Marsupenaeus japonicus. Zool. Sci., 24: 233-240. DOI:10. 2108/zsj.24.233.

Okuno, A., W. J. Yang, V. Jayasankar, H. Saido-Sakanaka, D. T. T. Huong, S. Jasmani, M. Atmomarsono, T. Subramoniam, N. Tsutsui, T. Ohira, I. Kawazoe, K. Aida \& M. N. WILDER, 2002. Deduced primary structure of vitellogenin in the giant freshwater prawn, Macrobrachium rosenbergii, and yolk processing during ovarian maturation. J. Exp. Zool., 292: 417-429. DOI:10.1002/jez.10083.

Peng, J., P. Wei, B. Zhang, Y. Zhao, D. Zeng, X. Chen, M. Li \& X. Chen, 2015. Gonadal transcriptomic analysis and differentially expressed genes in the testis and ovary of the Pacific white shrimp (Litopenaeus vannamei). BMC Genomics, 16: 1-18. DOI:10.1186/s12864-0152219-4.

Phiriyangkul, P., P. Puengyam, I. B. Jakobsen \& P. Utarabhand, 2007. Dynamics of vitellogenin mRNA expression during vitellogenesis in the banana shrimp Penaeus (Fenneropenaeus) merguiensis using real-time PCR. Mol. Reprod. Dev., 74: 1198-1207. DOI:10.1002/ mrd.20629.

Phiriyangkul, P. \& P. UtARABhAnd, 2006. Molecular characterization of a cDNA encoding vitellogenin in the banana shrimp, Penaeus (Litopenaeus) merguiensis and sites of vitellogenin mRNA expression. Mol. Reprod. Dev., 73: 410-423. DOI:10.1002/mrd.20424.

Raviv, S., S. Parnes, C. Segall, C. Davis \& A. SAgi, 2006. Complete sequence of Litopenaeus vannamei (Crustacea: Decapoda) vitellogenin cDNA and its expression in endocrinologically induced sub-adult females. Gen. Comp. Endocrinol., 145: 39-50. DOI:10.1016/j.ygcen.2005. 06.009.

Ronquist, F., M. Teslenko, P. van der Mark, D. L. Ayres, A. Darling, S. Höhna, B. Larget, L. Liu, M. A. Suchard \& J. P. Huelsenbeck, 2012. MrBayes 3.2: efficient Bayesian phylogenetic inference and model choice across a large model space. Syst. Biol., 61: 539-542. DOI:10.1093/sysbio/sys029.

Shen, H., Y. Hu, Y. MA, X. Zhou, Z. Xu, Y. Shui, C. Li, P. Xu \& X. Sun, 2014. In-depth transcriptome analysis of the red swamp crayfish Procambarus clarkii. PLoS One, 9: 1-13. DOI:10.1371/journal.pone.0110548. 
SiB [Swiss Institute of Bioinformatics Members], 2016. The SIB Swiss Institute of Bioinformatics' resources: focus on curated databases. Nucleic Acids Res., 44: 27-37. DOI:10. 1093/nar/gkv1310.

SmolenaArs, M. M., O. Madsen, K. W. Rodenburg \& D. J. van Der Horst, 2007. Molecular diversity and evolution of the large lipid transfer protein superfamily. J. Lipid Res., 48: 489502. DOI:10.1194/jlr.R600028-JLR200.

Tarrant, A. M., M. F. Baumgartner, B. H. Hansen, D. Altin, T. Nordtug \& A. J. OLSEN, 2014. Transcriptional profiling of reproductive development, lipid storage and molting throughout the last juvenile stage of the marine copepod Calanus finmarchicus. Front. Zool., 11: 1-15. DOI:10.1186/s12983-014-0091-8.

Thongda, W., J. S. Chung, N. Tsutsui, N. ZMora \& A. KATEnTA, 2015. Seasonal variations in reproductive activity of the blue crab, Callinectes sapidus: Vitellogenin expression and levels of vitellogenin in the hemolymph during ovarian development. Comp. Biochem. Physiol., (A, Mol. Integr. Physiol.) 179: 35-43. DOI:10.1016/j.cbpa.2014.08.019.

Tiu, S. H., J. H. L. Hui, J. G. He, S. S. Tobe \& S. M. Chan, 2006a. Characterization of vitellogenin in the shrimp Metapenaeus ensis: expression studies and hormonal regulation of MeVg1 transcription in vitro. Mol. Reprod. Dev., 73: 424-436. DOI:10.1002/mrd.20433.

TiU, S. H., J. H. L. Hui, A. S. C. MAK, J. HE \& S. M. Chan, 2006b. Equal contribution of hepatopancreas and ovary to the production of vitellogenin $(\mathrm{PmVg} 1)$ transcripts in the tiger shrimp, Penaeus monodon. Aquaculture, 254: 666-674. DOI:10.1016/j.aquaculture.2005.11. 001.

Tsang, W. S., L. S. Quackenbush, B. K. C. Chow, S. H. K. Tiu, J. G. He \& S. M. Chan, 2003. Organization of the shrimp vitellogenin gene: evidence of multiple genes and tissue specific expression by the ovary and hepatopancreas. Gene, 303: 99-109. DOI:10.1016/S03781119(02)01139-3.

Tseng, D. Y., Y. N. Chen, G. H. Kou, C. F. Lo \& C. M. Kuo, 2001. Hepatopancreas is the extraovarian site of vitellogenin synthesis in black tiger shrimp, Penaeus monodon. Comp. Biochem. Physiol., (A, Mol. Integr. Physiol.) 129: 909-917. DOI:10.1016/S10956433(01)00355-5.

TsukimurA, B., 2001. Crustacean vitellogenesis: its role in oocyte development. Am. Zool., 41: 465-467. DOI:10.1093/icb/41.3.465.

Tsutsui, N., I. Kawazoe, T. OhiRa, S. Jasmani, W. J. Yang, M. N. Wilder \& K. Aida, 2000. Molecular characterization of a cDNA encoding vitellogenin and its expression in the hepatopancreas and ovary during vitellogenesis in the kuruma prawn, Penaeus japonicus. Zool. Sci., 17: 651-660. DOI:10.2108/zsj.15.651.

Uengwetwanit, T., P. Ponza, D. Sangsrakru, D. Wichadakul, S. Ingsriswang, R. LeeLAtanawit, S. Klinbunga, S. TAngPhatsornruang \& N. Karoonuthaisiri, 2018. Transcriptome-based discovery of pathways and genes related to reproduction of the black tiger shrimp (Penaeus monodon). Mar. Genomics, 37: 69-73. DOI:10.1016/j.margen.2017.08. 007.

Wang, Z., S. Luan, X. Meng, B. CaO, K. Luo \& J. Kong, 2019. Comparative transcriptomic characterization of the eyestalk in Pacific white shrimp (Litopenaeus vannamei) during ovarian maturation. Gen. Comp. Endocrinol., 274: 60-72. DOI:10.1016/j.ygcen.2019.01.002.

Wong, Q. W., W. Y. MAK \& K. H. CHU, 2008. Differential gene expression in hepatopancreas of the shrimp Metapenaeus ensis during ovarian maturation. Mar. Biotechnol., 10: 91-98. DOI:10. 1007/s10126-007-9042-0.

Wu, H., F. Z. Jiang, J. X. Guo, J. Q. Yi, J. B. Liu, Y. S. CaO, X. S. Lai \& G. R. Zhang, 2018. Molecular characterization and expression of vitellogenin and vitellogenin receptor of Thitarodes pui (Lepidoptera: Hepialidae), an insect on the Tibetan plateau. J. Ins. Sci., 18: 1-7. DOI:10.1093/jisesa/iey010. 
XIE, S., L. Sun, F. LIU \& B. Dong, 2009. Molecular characterization and mRNA transcript profile of vitellogenin in Chinese shrimp, Fenneropenaeus chinensis. Mol. Biol. Rep., 36: 389-397. DOI:10.1007/s11033-007-9192-1.

Zhang, D., F. WANG, S. Dong \& Y. Lu, 2016. De novo assembly and transcriptome analysis of osmoregulation in Litopenaeus vannamei under three cultivated conditions with different salinities. Gene, 78: 185-193. DOI:10.1016/j.gene.2015.12.026.

Zmora, N., J. Trant, S. M. Chan \& J. S. ChUng, 2007. Vitellogenin and its messenger RNA during ovarian development in the female blue crab, Callinectes sapidus: gene expression, synthesis, transport, and cleavage. Biol. Reprod., 77: 138-146. DOI:10.1095/biolreprod.106. 055483.

Zmora, N., J. Trant, Y. Zohar \& J. S. Chung, 2009. Molt-inhibiting hormone stimulates vitellogenesis at advanced ovarian developmental stages in the female blue crab, Callinectes sapidus 1: an ovarian stage dependent involvement. Saline Systems., 5: 1-11. DOI:10.1186/ 1746-1448-5-7.

\section{SUPPLEMENTARY MATERIAL}

The seven tables presented in Supplementary Material as well as the corresponding references, follow below. 


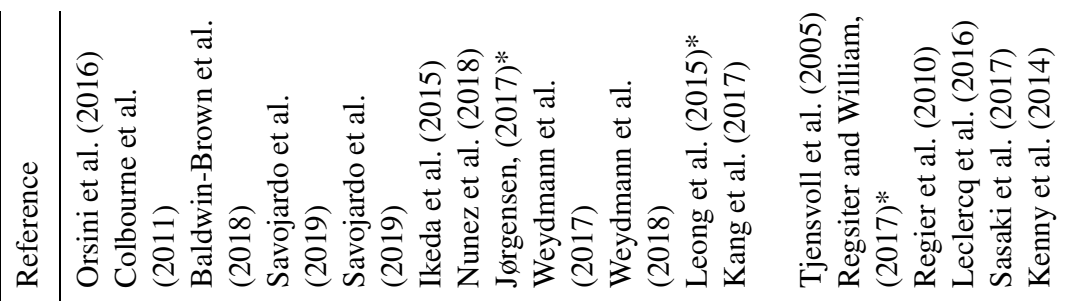

$\Theta$

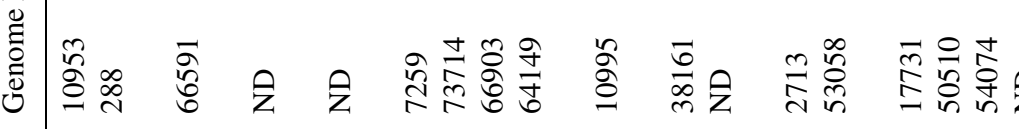

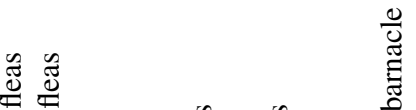

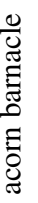

जิ

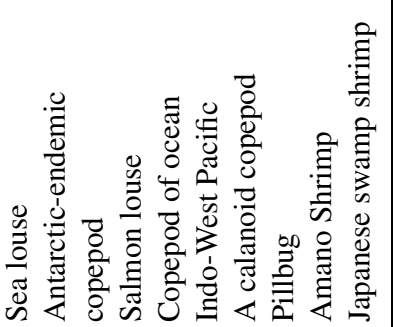

文

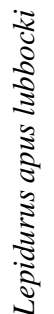

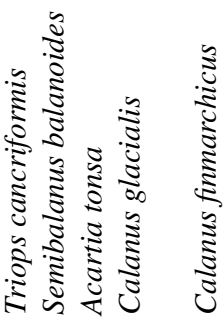

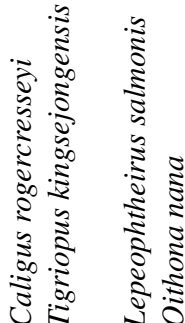

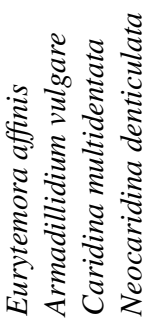

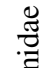

(1)

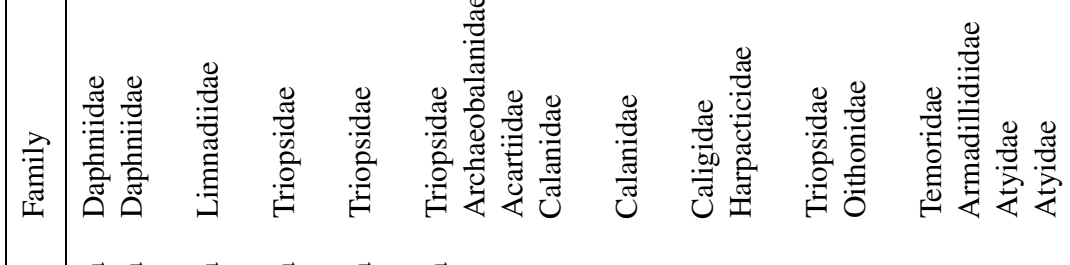

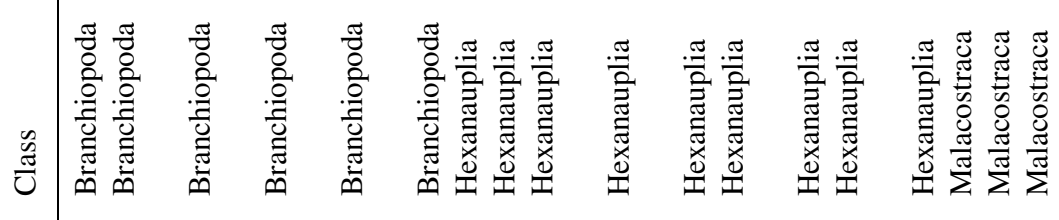

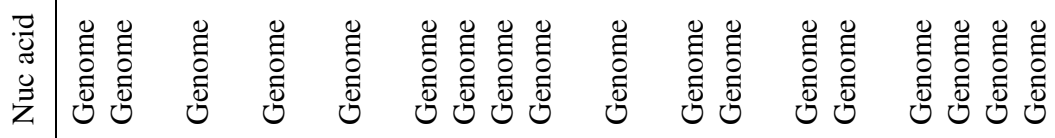

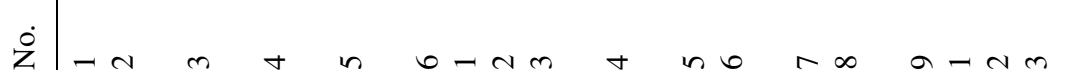




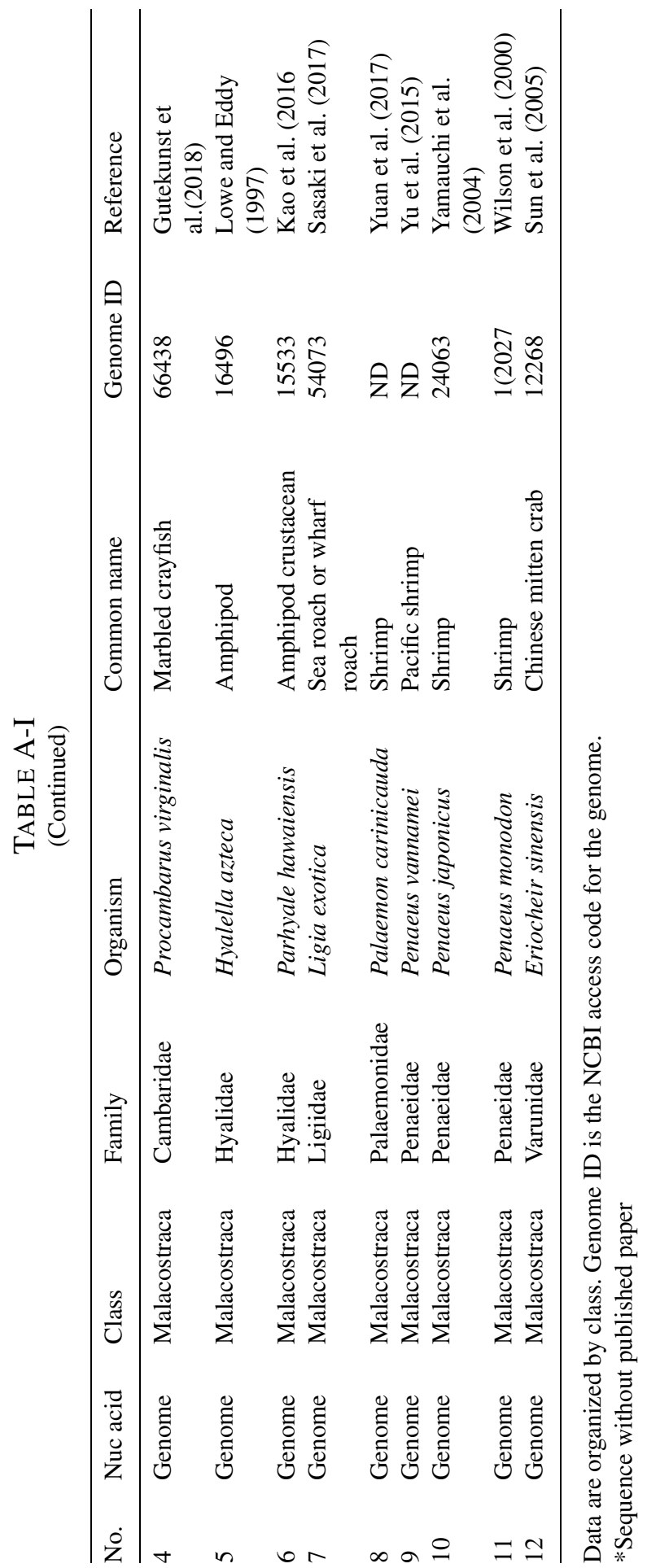




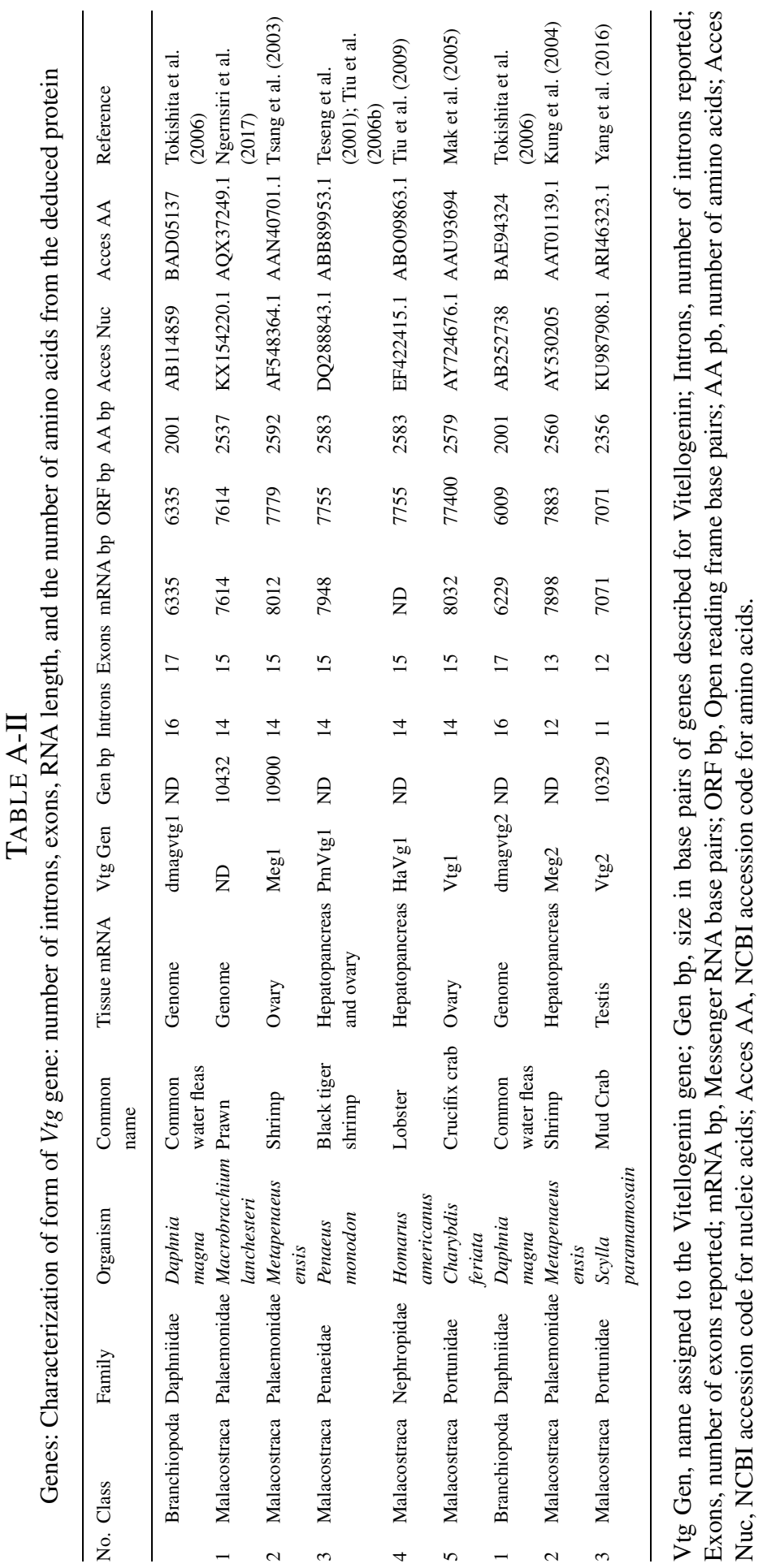




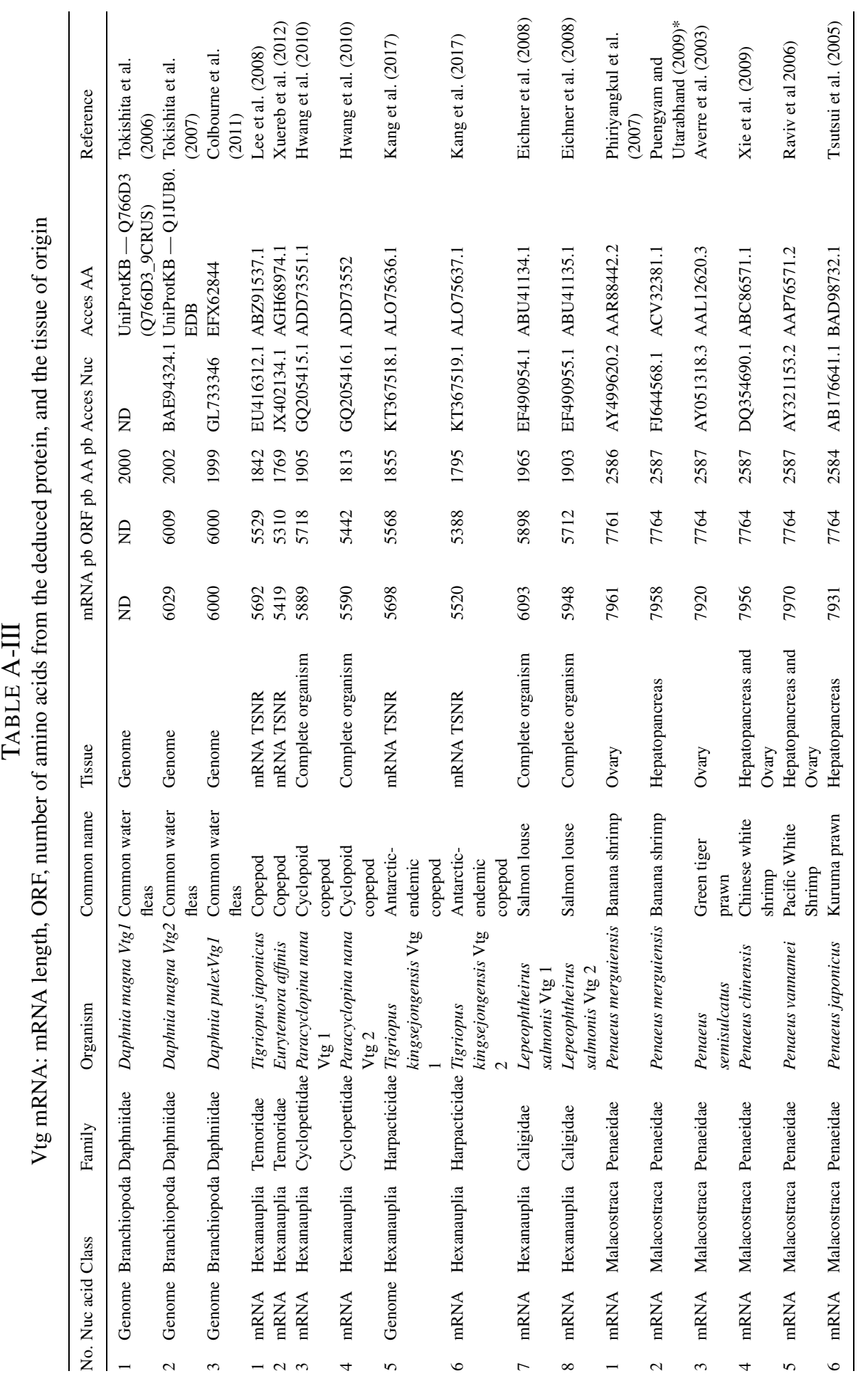




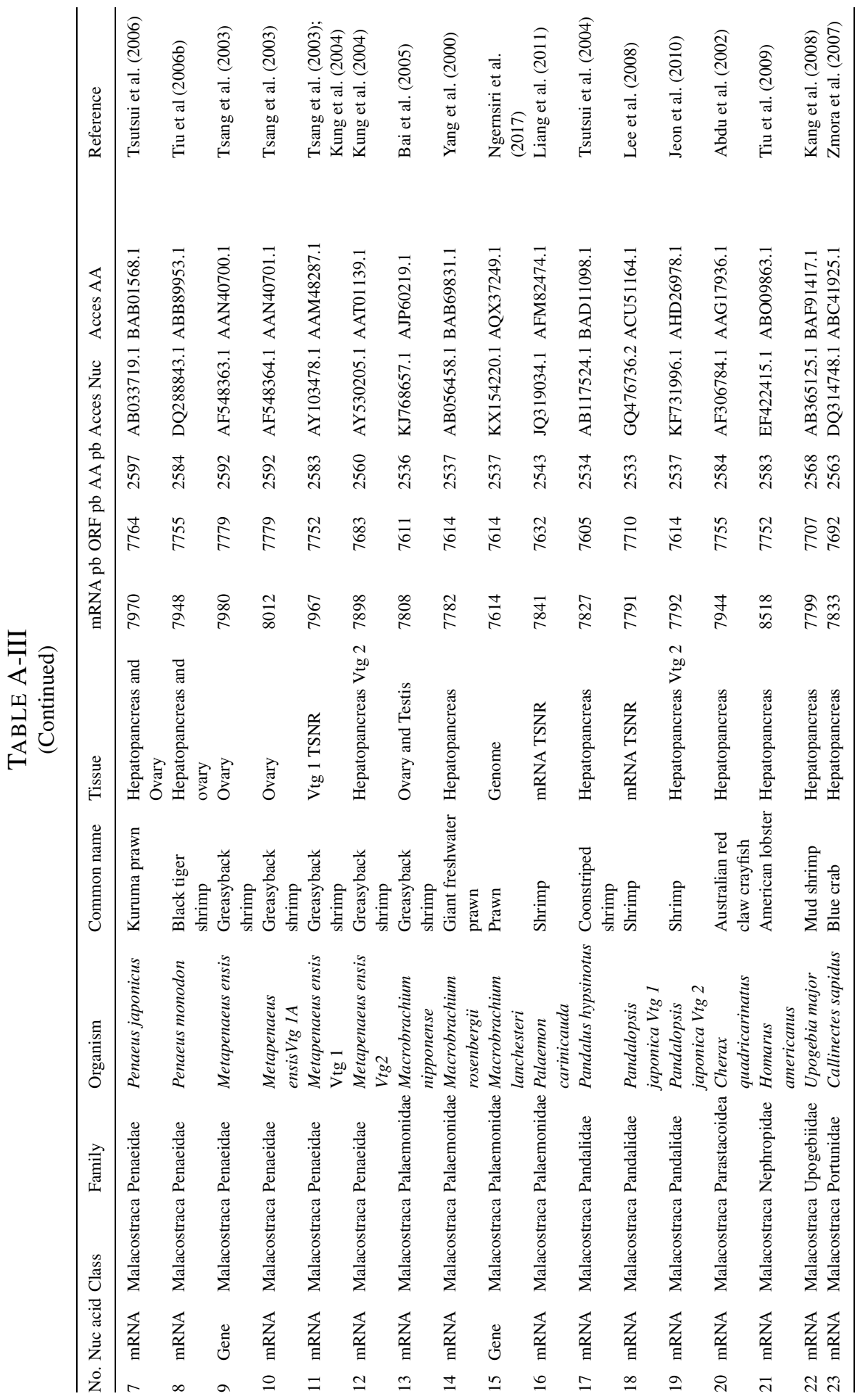




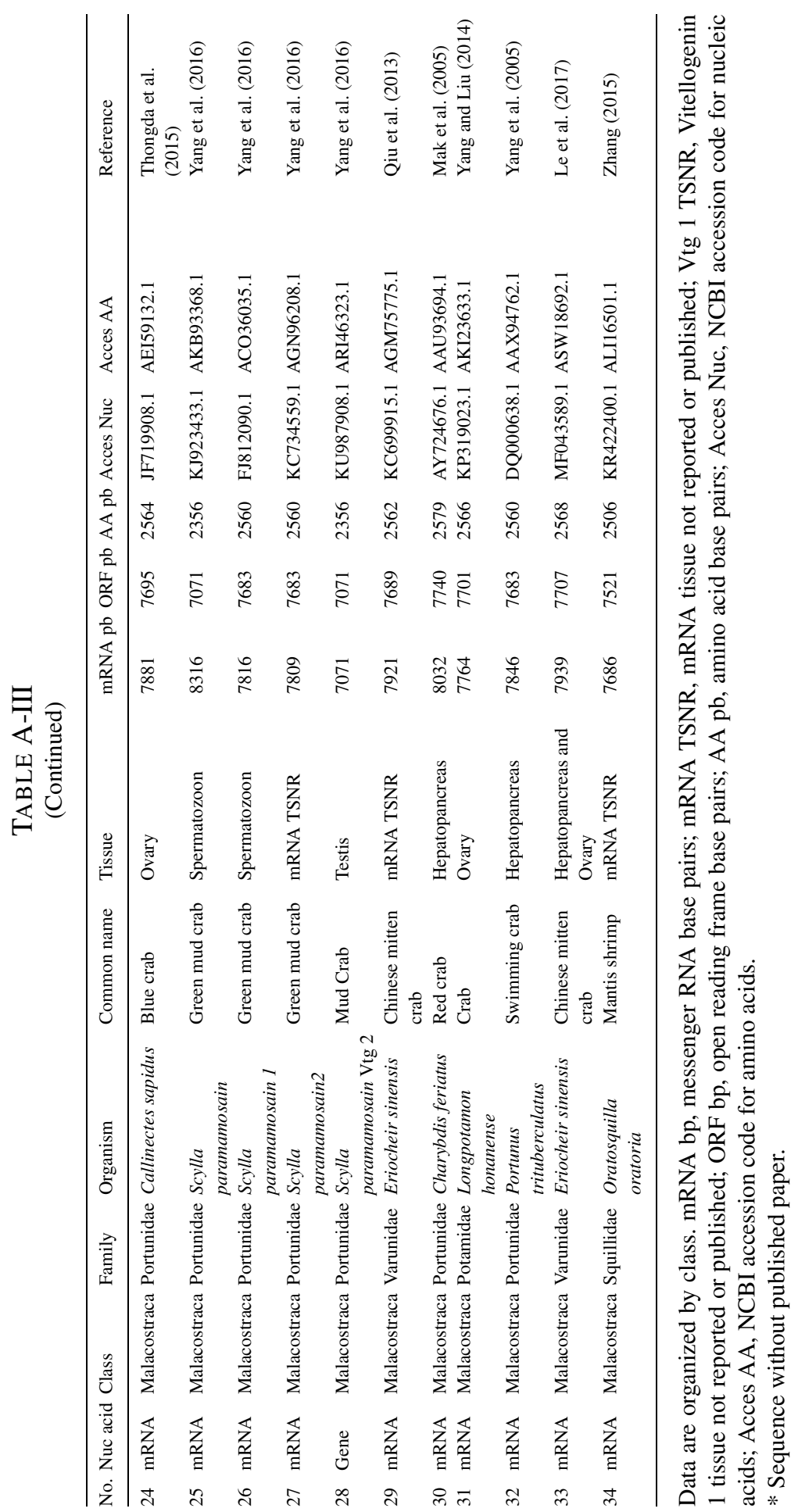




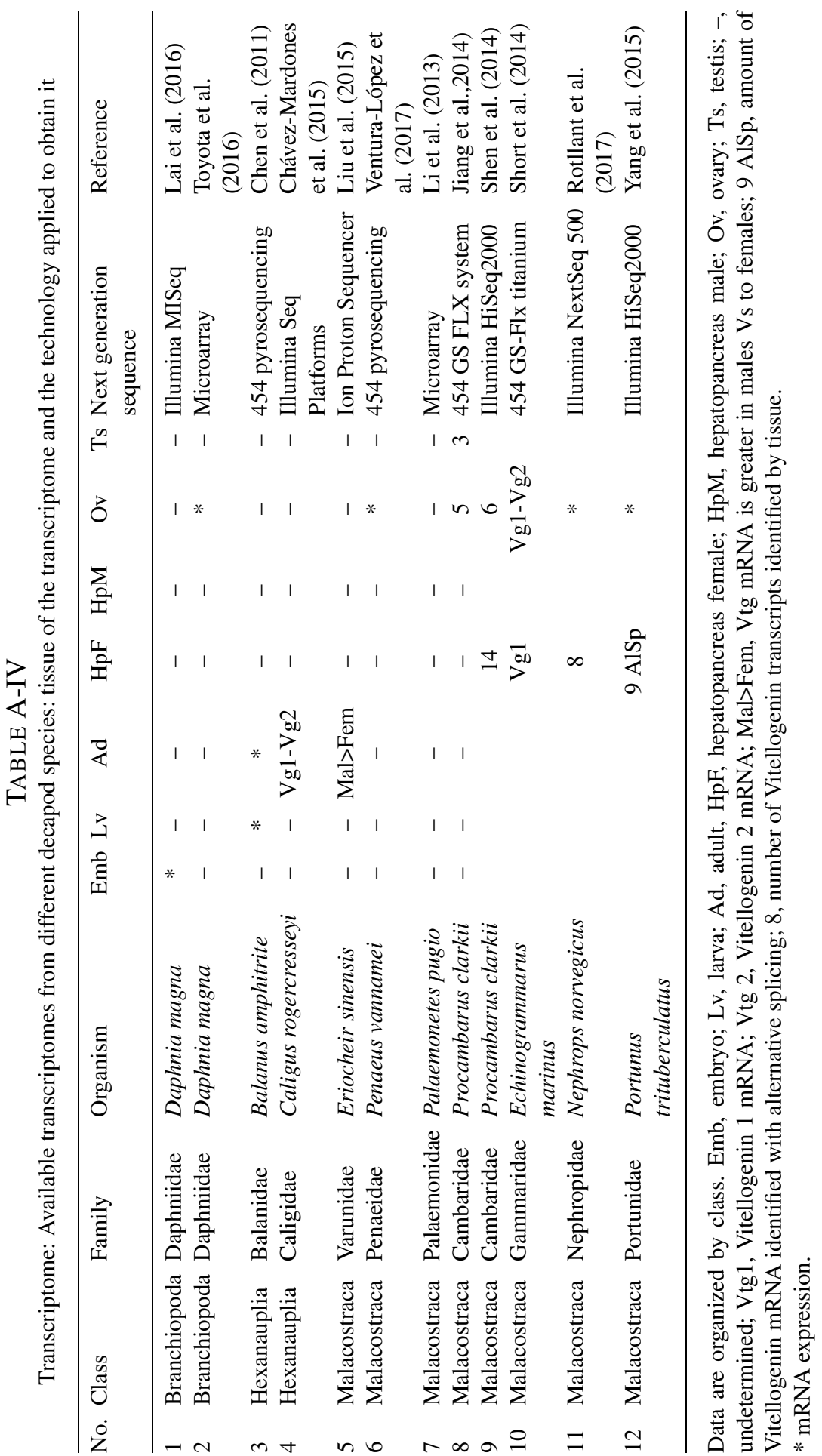




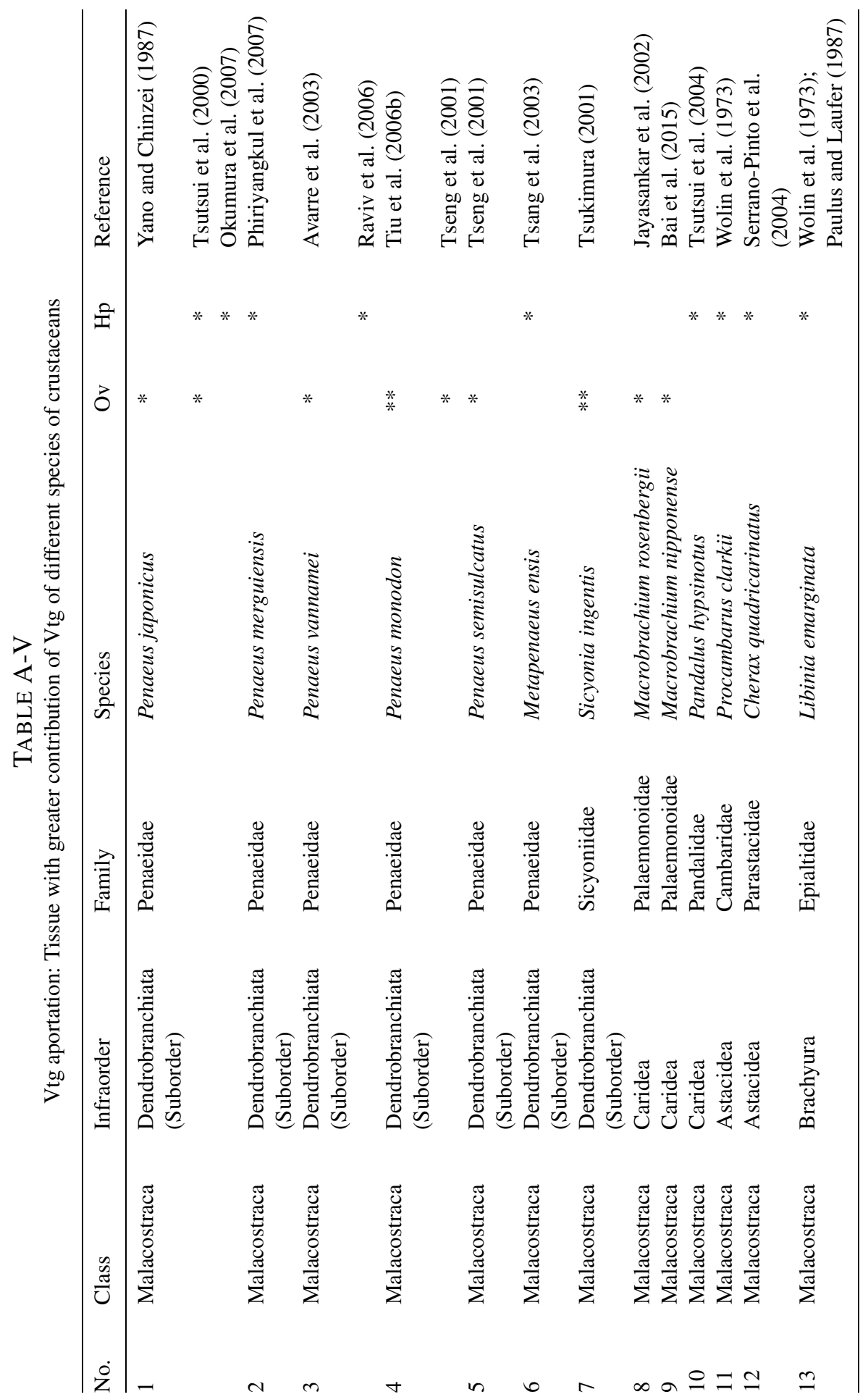




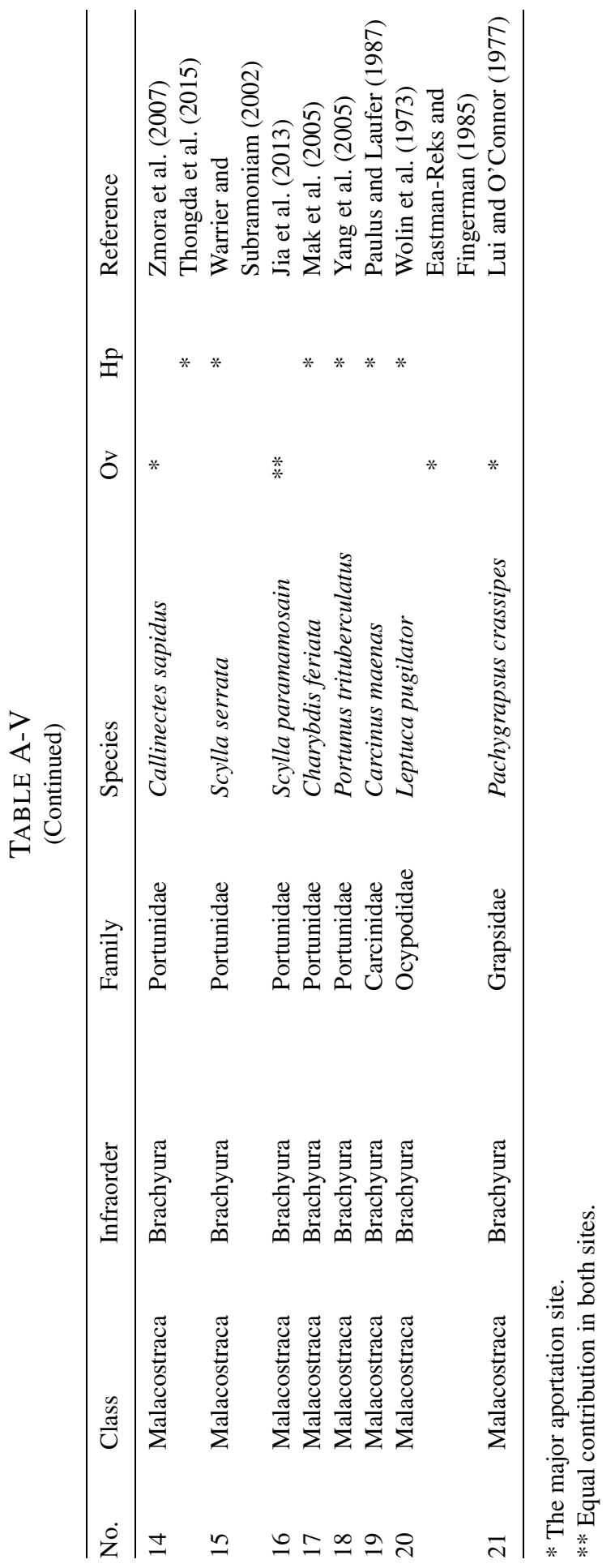




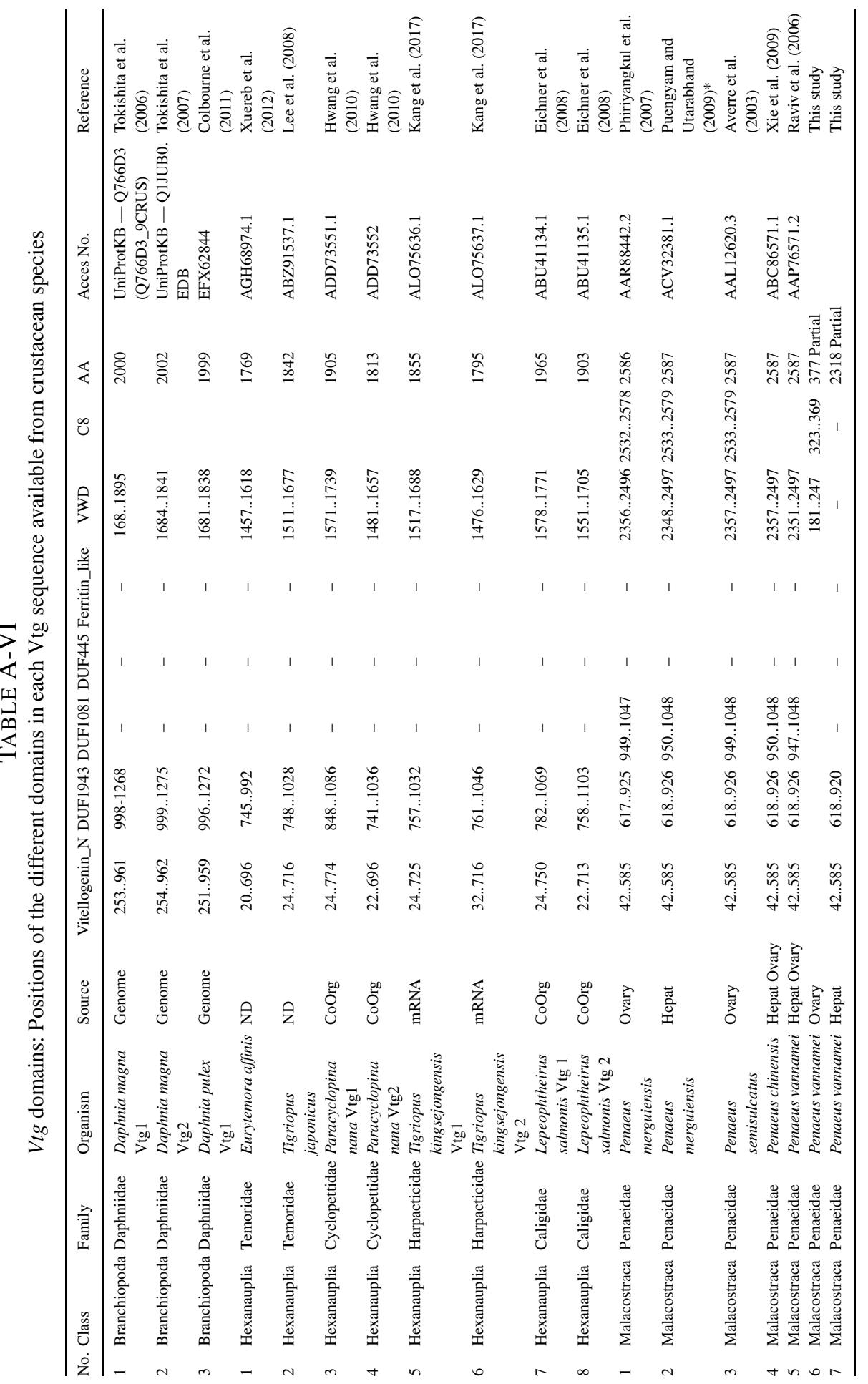




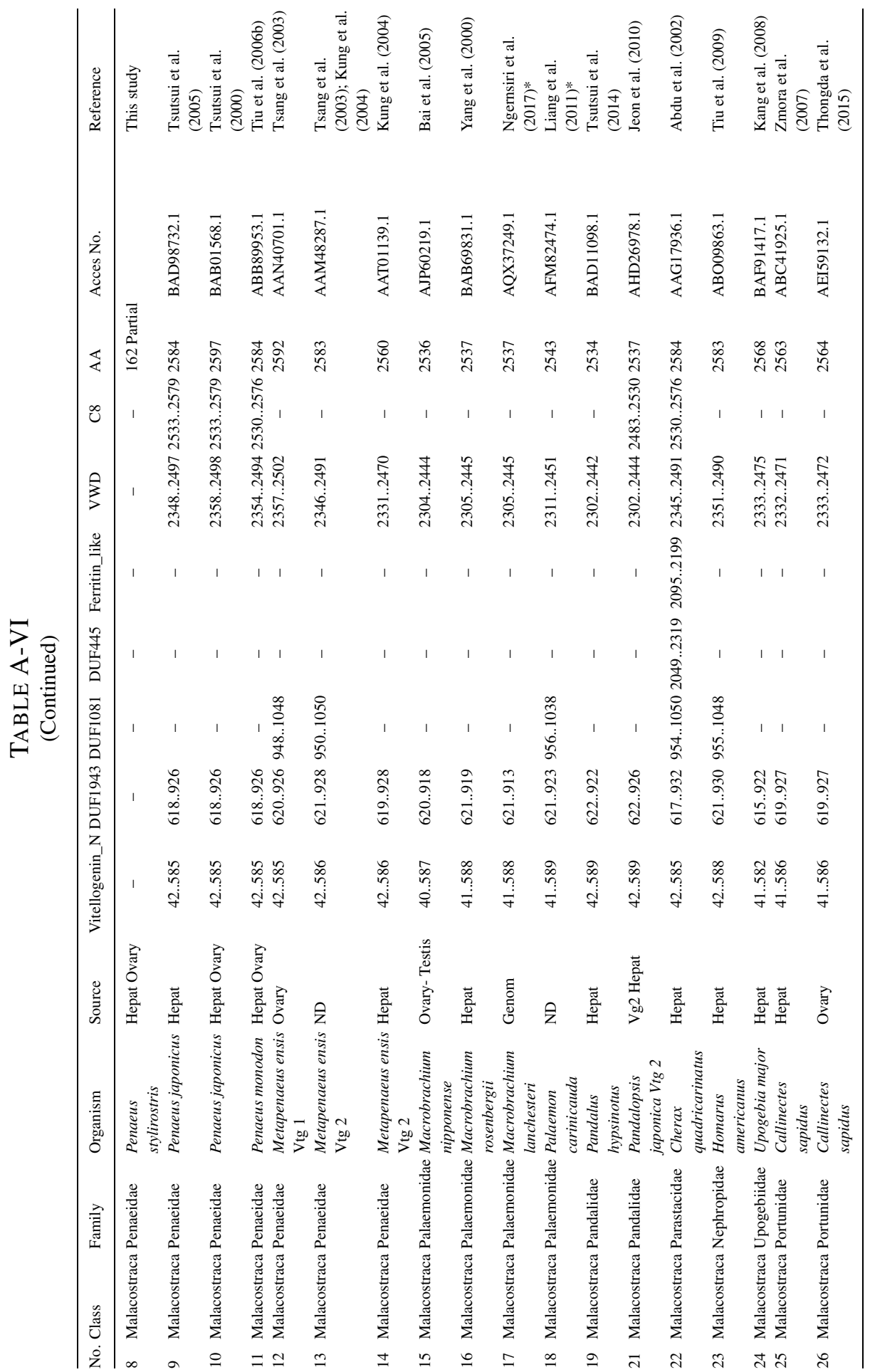




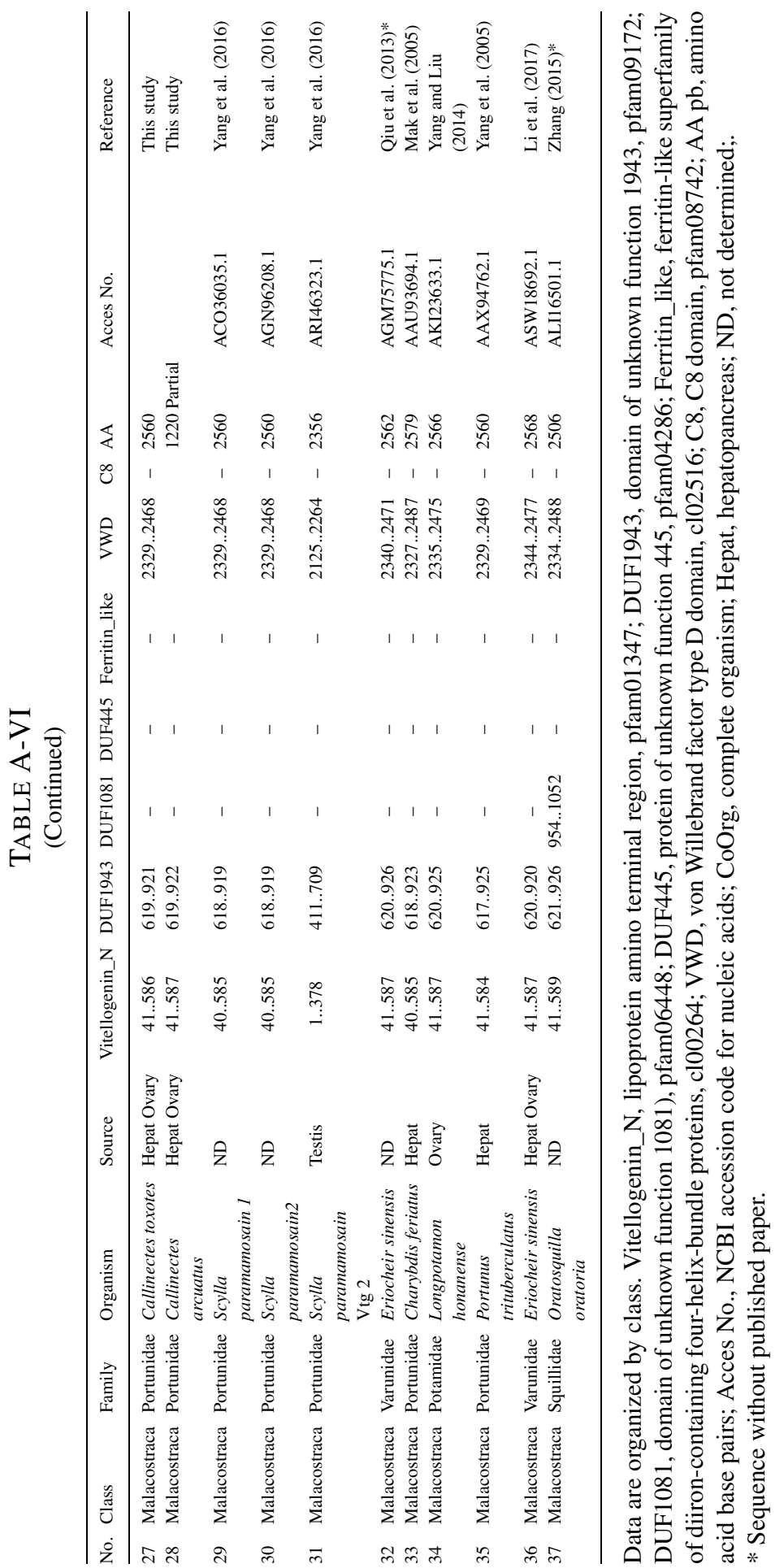




\section{TABLE A-VII}

Vtg regulation: Physiological factors and responses in regulation of reproduction in crustacean species

\begin{tabular}{|c|c|c|}
\hline Factor & Effect & Reference \\
\hline Juvenile organism & Absence of $V t g$ and $V I H$ & This study \\
\hline \multirow[t]{4}{*}{ Ovary development (I-IV) } & Decreases VIH levels & Okumura (2007) \\
\hline & Increase proportionally Vtg mRNA and & Kung et al. (2004); \\
\hline & Vtg synthesis & Thongda et al. (2007) \\
\hline & $\begin{array}{l}\text { Increase MIH levels, without significant } \\
\text { changes in } M I H \text { expression }\end{array}$ & Zmora et al. (2009) \\
\hline VIH & $\begin{array}{l}\text { Affects } V t g \text { expression depending on the } \\
\text { ovarian-stage }\end{array}$ & $\begin{array}{l}\text { This study; Bae et al. } \\
\text { (2017) }\end{array}$ \\
\hline \multirow[t]{3}{*}{ Ecdysis (moult) } & $\begin{array}{l}\text { Does not occur at the same time as the } \\
\text { reproduction }\end{array}$ & Zmora et al. (2009) \\
\hline & $\begin{array}{l}\text { Increase } V t g \text { expression at initial } \\
\text { maturation stages }\end{array}$ & Gong et al. (2015) \\
\hline & $\begin{array}{l}\text { Decrease Vtg expression days before the } \\
\text { moult }\end{array}$ & Jayasankar et al. (2002) \\
\hline Post-moult & Upregulation of $V t g$ & Avarre et al. (2003) \\
\hline \multirow[t]{2}{*}{ MIH } & Negatively regulates ecdysteroidogenesis & Bae et al. (2017) \\
\hline & Suppresses the Y organ & $\begin{array}{l}\text { Zmora et al. (2009); Das } \\
\text { et al. (2018) }\end{array}$ \\
\hline High $\mathrm{Ca} 2+$ concentrations & $\begin{array}{l}\text { Abolish MIH effects, due to the enhanced } \\
\text { degradation of cAMP. }\end{array}$ & $\begin{array}{l}\text { Bae et al. (2017); Das et } \\
\text { al. (2018) }\end{array}$ \\
\hline Increasing $E c R$ mRNA & $\begin{array}{l}\text { Parallelly increase Vtg levels until ovary } \\
\text { stage III. }\end{array}$ & Gong et al. (2015) \\
\hline
\end{tabular}

\section{REFERENCES FOR SUPPLEMENTARY MATERIAL}

ABdu, U., C. DAVIS, I. Khalaila \& A. SAgi, 2002. The vitellogenin cDNA of Cherax quadricarinatus encodes a lipoprotein with calcium binding ability, and its expression is induced following the removal of the androgenic gland in a sexually plastic system. Gen. Comp. Endocrinol., 127: 263-272. DOI:10.1016/S0016-6480(02)00053-9.

Avarre, J.-C., R. Michelis, A. Tietz \& E. Lubzens, 2003. Relationship between vitellogenin and vitellin in a marine shrimp (Penaeus semisulcatus) and molecular characterization of vitellogenin complementary DNAs. Biol. Reprod., 69: 355-364. DOI:10.1095/biolreprod.102. 011627.

Bae, S. H., T. OKutsu, N. Tsutsui, B. J. Kang, H. Y. Chen \& M. N. Wilder, 2017. Involvement of second messengers in the signaling pathway of vitellogenesis-inhibiting hormone and their effects on vitellogenin mRNA expression in the whiteleg shrimp, Litopenaeus vannamei. Gen. Comp. Endocrinol., 246: 301-308. DOI:10.1016/j.ygcen.2017.01.006.

Bai, H., H. QiaO, F. Li, H. Fu, S. Sun, W. Zhang, S. Jina, Y. GonG, S. Jiang \& Y. XIOng, 2015. Molecular characterization and developmental expression of vitellogenin in the oriental river prawn Macrobrachium nipponense and the effects of RNA interference and eyestalk ablation on ovarian maturation. Gene, 562: 22-31. DOI:10.1016Zj.gene.2014.12.008.

Châvez-Mardones, J. \& C. Gallardo-EsCÂRate, 2015. Next-generation transcriptome profiling of the salmon louse Caligus rogercresseyi exposed to deltamethrin (AlphaMax ${ }^{\mathrm{TM}}$ ): discovery of relevant genes and sex-related differences. Mar. Biotechnol., 17: 793-810. DOI:10. 1007/s10126-015-9661-9. 
Chen, J. S., T. W. SAPpington \& A. S. RAIKhel, 1997. Extensive sequence conservation among insect, nematode, and vertebrate vitellogenin reveals common ancestry. J. Mol. Evol., 44: 440451. DOI:10.1007/PL00006164.

Chen, Z. F., K. Matsumura, H. Wang, S. M. Arellano, X. Yan, I. Alam, J. A. C. Archer, V. B. BAJIC \& P. Y. QIAN, 2011. Toward an understanding of the molecular mechanisms of barnacle larval settlement: a comparative transcriptomic approach. PLoS ONE, 6: e22913. DOI:10.1371/journal.pone.0022913.

Colbourne, J. K., M. E. Pfrender, D. Gilbert, W. K. Thomas, A. Tucker, T. H. OAkley, S. Tokishita, A. Aerts, G. J. Arnold, M. K. Basu, D. J. Bauer, C. E. CÂceres, L. Carmel, C. Casola, J.-H. Choi, J. C. Detter, Q. Dong, S. Dusheyko, B. D. Eads, T. Frohlich, K. A. Geiler-Samerotte, D. Gerlach, P. Hatcher, S. Jogdeo, J. Krijgsveld, E. V. Kriventseva, D. Kültz, C. Laforsch, E. Lindquist, J. Lopez, J. R. Manak, J. Muller, J. Pangilinan, R. P. Patwardhan, S. Pitluck, E. J. Pritham, A. Rechtsteiner, M. Rho, I. B. Rogozin, O. Sakarya, A. Salamov, S. Schaack, H. Shapiro, Y. Shiga, C. Skalitzky, Z. Smith, A. Souvorov, W. Sung, Z. Tang, D. Tsuchiya, H. Tu, H. Vos, M. Wang, Y. I. Wolf, H. Yamagata, T. Yamada, Y. Ye, J. R. Shaw, J. Andrews, T. J. Crease, H. Tang, S. M. Lucas, H. M. Robertson, P. Bork, E. V. KoOnin, E. M. Zdobnov, I. V. Grigoriev, M. LynCH \& J. L. Boore, 2011. The ecoresponsive genome of Daphnia pulex. Science, 331: 555-561. DOI:10.1126/science. 1197761.

Das, S., L. Vraspir, W. Zhou, D. S. Durica \& D. L. Mykles, 2018. Transcriptomic analysis of differentially expressed genes in the molting gland (Y-organ) of the blackback land crab, Gecarcinus lateralis, during molt-cycle stage transitions. Comp. Biochem. Physiol., (D, Genomics Proteomics) 28: 37-53. DOI:10.1016/jxbd.2018.06.001.

EASTMAN-REKS, S. B. \& M. Fingerman, 1985. In vitro synthesis of vitellin by the ovary of the fiddler crab, Uca pugilator. J. Exp. Zool., 233: 111-116.

Eichner, C., P. Frost, B. Dysvik, I. Jonassen, B. Kristiansen \& F. Nilsen, 2008. Salmon louse (Lepeophtheirus salmonis) transcriptomes during post molting maturation and egg production, revealed using EST-sequencing and microarray analysis. BMC Genomics, 9: 1-15. DOI:10.1186/1471-2164-9-126.

Gong, J., H. Ye, Y. Xie, Y. Yang, H. Huang, S. Li \& C. Zeng, 2015. Ecdysone receptor in the mud crab Scylla paramamosain: a possible role in promoting ovarian development. J. Endocrinol., 224: 273-287. DOI:10.1530/J0E-14-0526.

Gutekunst, J., R. Andriantsoa, C. Falckenhayn, K. Hanna, W. Stein, J. Rasamy \& F. LYKO, 2018. Clonal genome evolution and rapid invasive spread of the marbled crayfish. Nature Ecol. Evol., 2: 567-572. DOI:10.1038/s41559-018-0467-9.

HuAng, X., B. Feng, H. HuANG \& H. Ye, 2017. In vitro stimulation of vitellogenin expression by insulin in the mud crab, Scylla paramamosain, mediated through PI3K/Akt/T0R pathway. Gen. Comp. Endocrinol., 250: 175-180. DOI:10.1016/j.ygcen.2017.06.013.

Hwang, D. S., K. W. LeE, J. Han, H. G. PARK, J. Lee, Y. M. LeE \& J. S. LeE, 2010. Molecular characterization and expression of vitellogenin $(\mathrm{Vg})$ genes from the cyclopoid copepod, Paracyclopina nana, exposed to heavy metals. Comp. Biochem. Physiol. C: Toxicology and Pharmacology, 151: 360-368. DOI:10.1016/jxbpc.2009.12.010.

Ikeda, K. T., Y. Hirose, K. Hiraoka, E. Noro, K. Fujishima, M. Tomita \& A. Kanai, 2015. Identification, expression, and molecular evolution of microRNAs in the "living fossil" Triops cancriformis (tadpole shrimp). RNA, 21: 230-242.

Jayasankar, V., N. Tsutsui, S. Jasmani, H. Saido-Sakanaka, W. J. Yang, A. Okuno, T. T. TRAN, K. AIDA \& M. N. WILDER, 2002. Dynamics of vitellogenin mRNA expression and changes in hemolymph vitellogenin levels during ovarian maturation in the giant freshwater prawn Macrobrachium rosenbergii. J. Exp. Zool., 293: 675-682. DOI:10.1002/jez.10167. 
JeOn, J. M., S. O. Lee, K. S. Kim, H. J. BAeK, S. Kim, I. K. Kim, D. J. MyKleS \& H. W. KIM, 2010. Characterization of two vitellogenin cDNAs from a Pandalus shrimp (Pandalopsis japonica): expression in hepatopancreas is down-regulated by endosulfan exposure. Comp. Biochem. Physiol. B: Biochem. Mol. Biol., 157: 102-112. DOI:10.1016/jxbpb.2010.05.006.

JiA, X., Y. CHEN, Z. ZoU, P. LIN, Y. WANG \& Z. ZHANG, 2013. Characterization and expression profile of Vitellogenin gene from Scylla paramamosain. Gene, 520: 119-130. DOI:10.1016Zj. gene.2013.02.035.

JiAnG, H., Z. XING, W. LU, Z. QIAN, H. YU \& J. LI, 2014. Transcriptome analysis of red swamp crawfish Procambarus clarkii reveals genes involved in gonadal development. PLoS ONE, 9: e0105122. DOI:10.1371/journal.pone.0105122.

Kang, B. J., T. Nanri, J. M. Lee, H. Saito, C. H. Han, M. Hatakeyama \& M. Saigusa, 2008. Vitellogenesis in both sexes of gonochoristic mud shrimp, Upogebia major (Crustacea): analyses of vitellogenin gene expression and vitellogenin processing. Comp. Biochem. Physiol. B: Biochem. Mol. Biol., 149: 589-598. DOI:10.1016/j.cbpb.2007.12.003.

KAnG, S., D. H. Ahn, J. H. LeE, S. G. LeE, I. Shin, J. LeE, G. S. Min, H. LEe, H. W. KiM, S. KiM $\&$ H. PARK, 2017. The genome of the Antarctic-endemic copepod, Tigriopus kingsejongensis. GigaScience, 6: 1-9. DOI:10.1093/gigascience/giw010.

Kao, D. G., A. Lai, E. Stamataki, S. Rosic, N. Konstantinides, E. Jarvis, A. Di DonFrancesco, N. Pouchina-Stancheva, M. Se'mon, M. Grillo, H. Bruce, S. Kumar, I. Siwanowicz, A. Le, A. Lemire, M. B. Eisen, C. Extavour, W. E. Browne, C. Wolff, M. Averof, N. H. Patel, P. Sarkies, A. Pavlopoulos \& A. Aboobaker, 2016. The genome of the crustacean Parhyale hawaiensis, a model for animal development, regeneration, immunity and lignocellulose digestion. ELife, 5: e20062. DOI:10.7554/eLife.20062.

Kenny, N. J., Y. W. Sin, X. Shen, Q. Zhe, W. Wang, T. F. Chan, S. S. Tobe, S. M. Shimeld, K. H. CHU \& J. H. HUI, 2014. Genomic sequence and experimental tractability of a new decapod shrimp model, Neocaridina denticulata. Mar. Drugs, 12: 1419-1437. DOI:10.3390/ md12031419.

Kung, S. Y., S.-M. Chan, J. H. L. Hui, W. S. Tsang, A. MaK \& J. G. He, 2004. Vitellogenesis in the sand shrimp, Metapenaeus ensis: the contribution from the hepatopancreas-specific vitellogenin gene (MeVg2). Biol. Reprod., 71: 863-870. DOI:10.1095/biolreprod.103.022905.

Lai, K. P., J. W. Li, C. Y. S. Chan, T. F. Chan, K. W. Y. Yuen \& J. M. Y. ChiU, 2016. Transcriptomic alterations in Daphnia magna embryos from mothers exposed to hypoxia. Aquat. Toxicol., 177: 454-463. DOI:10.1016/j.aquatox.2016.06.020.

LeclercQ, S., J. Thézé, M. A. Chebbi, I. Giraud, B. Moumen, L. Ernenwein, P. Grèvea, C. Gilberta \& R. Cordaux, 2016. Birth of a W sex chromosome by horizontal transfer of Wolbachia bacterial symbiont genome. Proc. Natl. Acad. Sci. USA, 113: 15036-15041. DOI:10.1073/pnas.1608979113.

Lee, K. W., D. S. Hwang, J. S. Rhee, J. S. Ki, H. G. Park, J. C. Ryu, S. Raisuddin \& J. S. LEE, 2008. Molecular cloning, phylogenetic analysis and developmental expression of a vitellogenin $(\mathrm{Vg})$ gene from the intertidal copepod Tigriopus japonicus. Comp. Biochem. Physiol. B: Biochem. Mol. Biol., 150: 395-402. DOI:10.1016/j.cbpb.2008.04.009.

Lee, S. R., J. H. Lee, A. R. Kim, S. Kim, H. Park, H. J. BaeK \& H. W. Kim, 2016. Three cDNAs encoding vitellogenin homologs from Antarctic copepod, Tigriopus kingsejongensis: cloning and transcriptional analysis in different maturation stages, temperatures, and putative reproductive hormones. Comp. Biochem. Physiol. B: Biochem. Mol. Biol., 192: 38-48. DOI:10.1016/j.cbpb.2015.11.008.

LI, L., X. J. LI, Y. M. WU, L. YANG, W. LI \& Q. WANG, 2017. Vitellogenin regulates antimicrobial responses in Chinese mitten crab, Eriocheir sinensis. Fish Shellfish Immunol., 69: 6-14. DOI:10.1016/j.fsi.2017.08.002. 
LI, T. \& M. BRouwer, 2013. Field study of cyclic hypoxic effects on gene expression in grass shrimp hepatopancreas. Comp. Biochem. Physiol. D: Genomics Proteomics, 8: 309-316. DOI:10.1016/jxbd.2013.09.001.

LUI, C. W. \& J. D. O'CONNOR, 1977. Biosynthesis of crustacean lipovitellin. III. The incorporation of labeled amino acids into the purified lipovitellin of the crab Pachygrapsus crassipes. J. Exp. Zool., 199: 105-108. DOI:10.1002/jez.1401990112.

LiU, Y., M. Hui, Z. CuI, D. Luo, C. Song, Y. Li \& L. LIU, 2015. Comparative transcriptome analysis reveals sex-biased gene expression in juvenile Chinese mitten crab Eriocheir sinensis. PLoS ONE, 10: e133068. DOI:10.1371/journal.pone.0133068.

LOWE, T. M. \& S. R. EDDY, 1997. tRNAscan-SE: a program for improved detection of transfer RNA genes in genomic sequence. Nucleic Acids Res., 25: 955-964.

MaK, A. S. C., C. L. Choi, J.-G. He, J. H. L. Hui, S. H. K. Tiu, S. S. Tobe \& S. M. Chan, 2005a. Vitellogenesis in the red crab, Charybdis feriatus: hepatopancreas-specific expression and farnesoic acid stimulation of vitellogenin gene expression. Mol. Reprod. Dev., 70: 288-300. DOI:10.1002/mrd.20213.

MaK, A. S. C., C. L. Choi, J. H. L. Hui, S. H. K. Tiu, J.-G. He, S. S. Tobe \& S. M. Chan, 2005b. Hepatopancreas-specific expression and farnesoic acid stimulation of vitellogenin gene expression. Mol. Reprod. Dev., 70: 288-300. DOI:10.1196/annals.1327.008.

Nunez, J. C., R. G. Elyanow, D. A. Ferranti \& D. M. Rand, 2018. Population genomics and biogeography of the northern acorn barnacle (Semibalanus balanoides) using pooled sequencing approaches. In: Population genomics: 1-30. (Springer, Cham). DOI:10.1007/ 13836_2018_58.

OKUMURA, T., 2007. Effects of bilateral and unilateral eyestalk ablation on vitellogenin synthesis in immature female kuruma prawns, Marsupenaeus japonicus. Zool. Sci., 24: 233-240. DOI:10. 2108/zsj.24.233.

Orsini, L., H. Marshall, M. Cuenca Cambronero, A. Chaturvedi, K. W. Thomas, M. E. Pfrender, K. I. SPANier \& L. De Meester, 2016. Temporal genetic stability in natural populations of the waterflea Daphnia magna in response to strong selection pressure. Mol. Ecol., 25: 6024-6038. DOI:10.1111/mec.13907.

PAulus, J. E. \& H. LAUfER, 1987. Vitellogenocytes in the hepatopancreas of Carcinus maenas and Libinia emarginata (Decapoda, Brachyura). Int. J. Invertebr. Reprod. Dev., 11: 29-44.

Phiriyangkul, P., P. Puengyam, I. B. Jakobsen \& P. Utarabhand, 2007. Dynamics of vitellogenin mRNA expression during vitellogenesis in the banana shrimp Penaeus (Fenneropenaeus) merguiensis using real-time PCR. Mol. Reprod. Dev., 74: 1198-1207. DOI:10.1002/ mrd.20629.

PhiriYANGKul, P. \& P. UtARABhand, 2006. Molecular characterization of a cDNA encoding vitellogenin in the banana shrimp, Penaeus (Litopenaeus) merguiensis and sites of vitellogenin mRNA expression. Mol. Reprod. Dev., 73: 410-423. DOI:10.1002/mrd.20424.

RaViv, S., S. PARnes, C. Segall, C. DaVis \& A. SAGi, 2006. Complete sequence of Litopenaeus vannamei (Crustacea: Decapoda) vitellogenin cDNA and its expression in endocrinologically induced sub-adult females. Gen. Comp. Endocrinol., 145: 39-50. DOI:10.1016/j.ygcen.2005. 06.009 .

Rotllant, G., T. V. Nguyen, V. Sbragaglia, L. Rahi, K. J. Dudley, D. Hurwood, T. Ventura, J. B. Company, V. Chand, J. Aguzzi \& P. B. Mather, 2017. Sex and tissue specific gene expression patterns identified following de novo transcriptomic analysis of the Norway lobster, Nephrops norvegicus. BMC Genomics, 18: 1-14. DOI:10.1186/s12864-0173981-2.

SASAKI, M., Y. AKIYAMA-ODA \& H. ODA, 2017. Evolutionary origin of type IV classical cadherins in arthropods. BMC Evol. Biol., 17: 142. DOI:10.1186/s12862-017-0991-2. 
Savojardo, C., A. Luchetti, P. L. Martelli, R. Casadio \& B. Mantovani, 2019. Draft genomes and genomic divergence of two Lepidurus tadpole shrimp species (Crustacea, Branchiopoda, Notostraca). Mol. Ecol. Resources, 19: 235-244. DOI:10.1111/1755-0998. 12952.

Serrano-Pinto, V., I. Landais, M. H. Ogliastro, M. Gutiérrez-Ayala, H. Mejia-Ruiz, H. Villarreal-Colmenares, A. Garcia-Gasca \& C. VÂzQuez-Boucard, 2004. Vitellogenin mRNA expression in Cherax quadricarinatus during secondary vitellogenic at first maturation females. Mol. Reprod. Dev., 69: 17-21. DOI:10.1002/mrd.20157.

Shen, H., Y. Hu, Y. MA, X. Zhou, Z. XU, Y. Shui, C. LI, P. XU \& X. Sun, 2014. In-depth transcriptome analysis of the red swamp crayfish Procambarus clarkii. PLoS ONE, 9: e110548. DOI:10.1371/journal.pone.0110548.

ShORT, S., G. YANG, P. KILlE \& A. T. Ford, 2014. Vitellogenin is not an appropriate biomarker of feminisation in a Crustacean. Aquat. Toxicol., 153: 89-97. DOI:10.1016/j.aquatox.2013.11. 014.

Sun, H., K. ZHOU \& D. Song, 2005. Mitochondrial genome of the Chinese mitten crab Eriocheir japonica sinenesis (Brachyura: Thoracotremata: Grapsoidea) reveals a novel gene order and two target regions of gene rearrangements. Gene, 349: 207-217. DOI:10.1016/j.gene.2004.12. 036.

Thongda, W., J. S. Chung, N. Tsutsui, N. Zmora \& A. KATEnTA, 2014. Seasonal variations in reproductive activity of the blue crab, Callinectes sapidus: Vitellogenin expression and levels of vitellogenin in the hemolymph during ovarian development. Comparative Biochemistry and Physiology — Part A: Molecular and Integrative Physiology, 179(1): 35-43. DOI:10.1016/j. cbpa.2014.08.019.

TiU, S. H. K., J. H. L. Hui, J. G. He, S. S. Tobe \& S. M. Chan, 2006a. Characterization of vitellogenin in the shrimp Metapenaeus ensis: expression studies and hormonal regulation of MeVg1 transcription in vitro. Mol. Reprod. Dev., 73: 424-436. DOI:10.1002/mrd.20433.

TiU, S. H. K., J. H. L. Hui, A. S. C. MaK, J. G. HE \& S. M. Chan, 2006b. Equal contribution of hepatopancreas and ovary to the production of vitellogenin $(\mathrm{PmVg} 1)$ transcripts in the tiger shrimp, Penaeus monodon. Aquaculture, 254: 666-674. DOI:10.1016/j.aquaculture.2005.11. 001.

Tiu, S. H. K., J. H. L. Hui, B. Tsukimura, S. S. Tobe, J. G. HE \& S. M. Chan, 2009. Cloning and expression study of the lobster (Homarus americanus) vitellogenin: conservation in gene structure among decapods. Gen. Comp. Endocrinol., 160: 36-46. DOI:10.1016Zj.ygcen.2008. 10.014 .

TJensvoll, K., K. Hodneland, F. Nilsen \& A. Nylund, 2005. Genetic characterization of the mitochondrial DNA from Lepeophtheirus salmonis (Crustacea; Copepoda). A new gene organization revealed. Gene, 353: 218-230. DOI:10.1016/j.gene.2005.04.033.

Tokishita, S., Y. Kato, T. Kobayashi, S. Nakamura, T. Ohta \& H. Yamagata, 2006. Organization and repression by juvenile hormone of a vitellogenin gene cluster in the crustacean, Daphnia magna. Biochem. Biophys. Res. Commun., 345: 362-370. DOI:10.1016/ j.bbrc.2006.04.102.

Toyota, K., T. D. Williams, T. SATo, N. TATARaZako \& T. Iguchi, 2017. Comparative ovarian microarray analysis of juvenile hormone-responsive genes in water flea Daphnia magna: potential targets for toxicity. J. Appl. Toxicol., 37: 374-381. DOI:10.1002/jat.3368.

Tsang, W. S., L. S. Quackenbush, B. K. C. Chow, S. H. K. Tiu, J. G. He \& S. M. Chan, 2003. Organization of the shrimp vitellogenin gene: evidence of multiple genes and tissue specific expression by the ovary and hepatopancreas. Gene, 303: 99-109. DOI:10.1016/S03781119(02)01139-3.

TsenG, D. Y., Y. N. Chen, G. H. Kou, C. F. Lo \& C. M. KuO, 2001. Hepatopancreas is the extraovarian site of vitellogenin synthesis in black tiger shrimp, Penaeus monodon. Comp. Biochem. Physiol. A: Mol. Integr. Physiol., 129: 909-917. DOI:10.1016/S1095-6433(01)00355-5. 
TsukimuRA, B., 2001. Crustacean vitellogenesis: its role in oocyte development. Am. Zool., 41: 465-467.

Tsutsui, N., I. Kawazoe, T. Ohira, S. Jasmani, W.-J. Yang, M. N. Wilder \& K. Aida, 2000. Molecular characterization of a cDNA encoding vitellogenin and its expression in the hepatopancreas and ovary during vitellogenesis in the kuruma prawn, Penaeus japonicus. Zool. Sci., 17: 651-660. DOI:10.2108/zsj.17.651.

Tsutsui, N., Y. K. KIM, S. JASMAni, T. OHIRA, M. N. WILDER \& K. AidA, 2005. The dynamics of vitellogenin gene expression differs between intact and eyestalk ablated kuruma prawn Penaeus (Marsupenaeus) japonicus. Fish. Sci., 71: 249-256. DOI:10.1111/j.1444-2906.2005.00957.x.

Tsutsui, N., H. Saido-Sakanaka, W.-J. Yang, V. Jayasankar, S. Jasmani, A. Okuno, T. OHIRA, T. OKumura, K. AidA \& M. N. Wilder, 2004. Molecular characterization of a cDNA encoding vitellogenin in the coonstriped shrimp, Pandalus hypsinotus, and site of vitellogenin mRNA expression. J. Exp. Zool., 301: 802-814. DOI:10.1002/jez.a.

Ventura-López, C., P. E. Galindo-Torres, F. G. Arcos, C. Galindo-SÂnchez, I. S. RAcottA, C. Escobedo-Fregoso \& A. M. IBARRA, 2017. Transcriptomic information from Pacific white shrimp (Litopenaeus vannamei) ovary and eyestalk, and expression patterns for genes putatively involved in the reproductive process. Gen. Comp. Endocrinol., 246: 164-182. DOI:10.1016/j.ygcen.2016.12.005.

WARRIER, S. \& T. SUBRAMONIAM, 2002. Receptor mediated yolk protein uptake in the crab Scylla serrata: crustacean vitellogenin receptor recognizes related mammalian serum lipoproteins. Mol. Reprod. Dev., 61: 536-548. DOI:10.1002/mrd.10106.

Weydmann, A., A. Przylucka, M. Lubosny, K. S. Walczynska, E. A. Serrâo, G. A. PEARSON \& A. BURZYNSKi, 2017. Mitochondrial genomes of the key zooplankton copepods Arctic Calanus glacialis and north Atlantic Calanus finmarchicus with the longest crustacean non-coding regions. Sci. Rep., 7: 13702. DOI:10.1038/s41598-017-13807-0.

Wilson, K., V. Cahill, E. Ballment \& J. Benzie, 2000. The complete sequence of the mitochondrial genome of the crustacean Penaeus monodon: are malacostracan crustaceans more closely related to insects than to branchiopods? Mol. Biol. Evol., 17: 863-874. DOI:10. 1093/oxfordjournals.molbev.a026366.

Wolin, E. M., H. LAufer \& D. F. Albertini, 1973. Uptake of the yolk protein, lipovitellin, by developing crustacean oocytes. Dev. Biol., 35: 160-170.

XIE, S., L. Sun, F. LIU \& B. Dong, 2009. Molecular characterization and mRNA transcript profile of vitellogenin in Chinese shrimp, Fenneropenaeus chinensis. Mol. Biol. Rep., 36: 389-397. DOI:10.1007/s11033-007-9192-1.

Xuereb, B., J. Forget-Leray, S. Souissi, O. Glippa, D. Devreker, T. Lesueur, S. Marie, J. M. DANGer \& C. BoulangÉ-LeCOMte, 2012. Molecular characterization and mRNA expression of grp78 and hsp90A in the estuarine copepod Eurytemora affinis. Cell Stress Chaperones, 14: 457-472. DOI:10.1007/s12192-012-0323-9.

YAMAUCHI, M. M., M. U. MiYA, R. J. MACHIDA \& M. NishidA, 2004. PCR-based approach for sequencing mitochondrial genomes of decapod crustaceans, with a practical example from kuruma prawn (Marsupenaeus japonicus). Mar. Biotechnol., 6: 419-429. DOI:10.1007/ s10126-003-0036-2.

YANG, F., H. T. XU, Z. M. DAI \& W. J. YANG, 2005. Molecular characterization and expression analysis of vitellogenin in the marine crab Portunus trituberculatus. Comp. Biochem. Physiol. B: Biochem. Mol. Biol., 142: 456-464. DOI:10.1016/jxbpb.2005.09.0n.

Yang, Y., J. Wang, T. Han, T. LiU, C. Wang, J. XiaO, C. Mu, R. Li, F. Yu \& H. Shi, 2015. Ovarian transcriptome analysis of Portunus trituberculatus provides insights into genes expressed during phase III and IV development. PLoS ONE, 10: e0138862. DOI:10.1371/ journal.pone.0138862. 
YANG, Y., B. ZHENG, C. BAO, H. HUANG \& H. YE, 2016. Vitellogenin2: spermatozoon specificity and immunoprotection in mud crabs. Reproduction, 152: 235-243. DOI:10.1530/REP-160188 .

YANO, I. \& Y. CHINZEI, 1987. Ovary is the site of vitellogenin synthesis in Kuruma prawn, Penaeus japonicus. Comp. Biochem. Physiol. B, 86: 213-218.

Yang, W. J., T. Ohira, N. Tsutsui, T. Subramonian, D. T. T. Huong, K. Aida \& M. N. WILDER, 2000. Determination of amino acid sequence and site of mRNA expression of four vitellins in the giant freshwater prawn, Macrobrachium rosenbergii. J. Exp. Zool., 287: 413422. DOI:10.1002/1097-010X(20001101)287:6<413::AID-JEZ2>3.0.CO;2-V.

Yu, Y., X. Zhang, J. Yuan, F. Li, X. Chen, Y. Zhao, L. Huang, H. Zheng \& J. Xiang, 2015. Genome survey and high-density genetic map construction provide genomic and genetic resources for the Pacific White Shrimp Litopenaeus vannamei. Sci. Rep., 5: 15612. DOI:10. 1038/srep15612.

Yuan, J., Y. GaO, X. Zhang, J. Wei, C. LiU, F. Li \& J. Xiang, 2017. Genome sequences of marine shrimp Exopalaemon carinicauda Holthuis provide insights into genome size evolution of Caridea. Mar. Drugs, 15: 213. DOI:10.3390/md15070213.

Zmora, N., J. Trant, S.-M. Chan \& J. S. Chung, 2007. Vitellogenin and its messenger RNA during ovarian development in the female blue crab, Callinectes sapidus: gene expression, synthesis, transport, and cleavage. Biol. Reprod., 77: 138-146. DOI:10.1095/biolreprod.106. 055483.

First received 7 April 2019.

Final version accepted 6 July 2019. 